\title{
6 \\ Closing illegitimate opportunities by separating powers
}

\section{Key propositions}

- The way to control the abuse of power is not to destroy power but to share it and temper it.

- A separation of powers into the legislature, the executive and the judiciary is insufficiently complex for the contemporary division of labour.

- In the world of contemporary capitalism, the separation of private powers is as important as the separation of public powers.

- Corruption is controlled by continual reinvention of new ways of sharing separated organisational powers so that domination is always being put off balance.

- Separated institutional powers must be able to pursue power up to the point where the power of one is not so strong as to overcome the power of the others. Each separated power must be strong enough, however, to secure the exercise of its own power from being dominated by any other institutional power.

- Workplace democracy has an important niche in a separation of powers.

- The deterrence trap means that sanctioning of an organisation sufficient to deter it may risk crippling it and crippling innocent citizens who depend on it. 
- One escape from the deterrence trap is to replace narrow, formal and strongly punitive responsibility (the 'find the crook' strategy) with broad, informal, weak sanctions.

- A second escape from the deterrence trap is to separate enforcement targeting from identification of the actor who benefits from the abuse of power. Together, this escape and the one above constitute a strength of weak sanctions.

- A third escape from the deterrence trap is to rely heavily on streetlevel bureaucrats who mobilise the 'relational state' and a wide mix of preventive strategies, each of which is weak as a standalone strategy, but strong when woven into a fabric of relational prevention. These street-level relational regulators can be police, state, self-regulatory or NGO inspectors, state or NGO welfare supporters or citizens who mobilise collective efficacy at street level.

- Separations of private power can be crafted to prevent corporate domination by a variety of well-tried techniques developed in this chapter (and summarised in Appendix I).

- Most fundamentally, crime prevention must shift its focus from hard targets who are committed to criminal subcultures to indirectly leveraging change through caring and prosocial actors who surround them - such as daughters, accountants or the priests of Mafia bosses or Wall Street predators alike.

\section{Old insights on checks and balances on white-collar crime}

If limiting the power of the powerful will reduce white-collar crime, how might this be achieved? The purpose of this chapter is to discuss some of the options that can be deployed to achieve a redistribution or tempering of power relevant to regulating the dynamics discussed in the preceding chapter. The strategies considered in this chapter and the next are not about destroying that power to get things done, but about sharing power to do so, and tempering power with checks and balances that make power less arbitrary and therefore less dominating. Then it is argued that tempered power can be more capable of getting good things done. All of that depends on contextual wisdom in the design of a rich plurality of separations of powers. 
After diagnosing secrecy and unaccountable power in the executive branch of government, Lieberman's (1973) study of state illegality concluded that open government, making all government reports open to the public, freedom of information legislation that works, unlimited freedom of the press, ombudsmen, welfare-rights officers, limitations on police power and the right for citizens and interest groups to challenge government decisions in court were all important. As a check on the arbitrary exercise of power, he perhaps idealistically argued for a convention whereby reasons accompany all official decisions. This is idealistic perhaps, but political institutions like US congressional oversight committees and daily question time that ministers and the prime minister cannot avoid in Westminster systems are institutional examples of practical paths to demanding this result. In this chapter, these are all theorised as suggestions for more variegated and complex separations of powers (drawing heavily on Braithwaite 1997).

The suggestions for limiting white-collar crime put forward by people with wide experience investigating business crime involve limiting the power of those in positions with great illegitimate opportunities. A former president of the US Fidelity \& Guaranty Co. made these suggestions long ago about limiting crime against companies by senior employees:

It is generally good practice not to put one employee in complete charge of any one phase of administration where accounts receivable or payable are involved; for example, a credit manager should not be permitted to receive money and at the same time be in charge of posting and deposits and the preparation, mailing and distribution of monthly statements to clients. Cashiers or accountants should prepare the reports of receipts, which should be verified by someone else who would be responsible in turn for deposits and the posting of ledgers. Shipping and receiving, whenever possible, should be two completely separate operations and the responsibility of at least two individuals, each having to submit individual returns to the accounting office. Collection receipts and bank deposits should be verified as to their individual entries and not as to totals only. And this should be done by someone other than the person preparing the statement. Also, the monthly itemized statement should be verified with the bank. Spot-checks, audits, and inventories should be made at frequent intervals, and on a surprise basis, and the results compared with other results that will corroborate them or prove them in error. (Jeffery 1970: 19) 
These are simple, practical examples of what I mean by sharing power to get things done rather than destroying it and sharing power in ways that enhance accountability. Jaspan and Black (1960) also drew on wide practical experience investigating white-collar crime during those early years of white-collar crime prevention. They made the following suggestions about how the limitation of the power of senior employees is central to a system of preventive management against white-collar crime:

Protection from fraud demands that work be subdivided so that no employee has complete control over any record or transaction. Responsibility is allocated so that, without duplicate effort, an employee verifies the work of others in the normal course of his duties. This check and review which is inherent in any good system of control, greatly reduces the possibility that errors or fraud remain undetected for inordinate periods. The following are examples of how dual responsibility is maintained over typical work functions: 1 . The preparation of the payroll and the payment of employees is handled by two different groups of employees, especially if employees are paid in cash. 2. Persons who maintain inventory records are not allowed to participate in the actual physical counting of inventory. 3. Persons approving payments on invoices or customers' bills are not allowed to participate in the actual receiving of supplies or merchandise. 4. Shipping records are matched against billings to customers by employees in two different departments. 5. Wrappers in stores compare items and prices on sales checks made out by sales clerks with the items to be wrapped. 6. Employees in sensitive positions are rotated from one job to another. For example, branch managers should be periodically shifted to different stores, warehouses, sales offices. Truck drivers' routes can be changed. Factory foremen and supervisors should be rotated. Payroll and accounts receivable clerks who handle alphabetical listings should be shifted from say a, b listings to e, f listings. (Jaspan and Black 1960: 248)

The next chapter describes contemporary markets in crime-prevention software; these have assisted such separations greatly. For example, in customs authorities, if one official records the value of a traded item for the calculation of customs duty, it is only possible for designated officials to change this, and for any official who does change it, this can only be done by an electronic signature being left behind identifying the person who made the change. Most of these measures are geared to catching people at middle levels of management who offend against the organisation itself. There always was clear evidence that the amounts of money involved in 
these kinds of offences increase dramatically as we move up the hierarchy of the firm (Jaspan and Black 1960: 51-52). This reality can be combined with a prosecution strategy of threatening the small fish responsible for small takings with prison unless they give up a bigger fish, then the bigger fish is offered the opportunity to give up an even bigger fish, until the sharks responsible for massive takings are netted. This was the strategy that enabled New York prosecutors to move up to potent penalties for the massive crimes of Michael Milken and other senior figures of the 'greed is good' frauds of late 1980s Wall Street.

Writers such as Sharpston (1970) suggested the solution to corruption was to change radically the situation in which power was concentrated in a few hands. Industrial democracy could help structurally to temper opportunities for crime enjoyed by managers. It could increase scrutiny of the behaviour of managers where opportunities for illegitimate discretion remained. If the accounts of a firm can be scrutinised under workplace democracy, the more democratic workplace poses a more constant risk that cheating will be unmasked by employees checking the books against the facts of workers' daily organisational experience, sometimes with professional accounting or union advice. A union grapevine can provide an intelligence network - gratis - that no government regulator could hope to rival. This may be why the unusual level of industrial democracy in the old underground coalmining industry in the United States and other western democracies resulted in unionised mines with elected union safety inspectors recording far lower rates of miners killed and injured (Braithwaite 1985). It is hard to escape the conclusion that this was because the institutionalisation of old-fashioned industrial democracy meant that miners, and especially their elected safety representatives, were looking over the shoulders of company safety and production executives. Workplace democracy is less fashionable today. If we want a society free from dominations that kill, making it fashionable again merits consideration as an evidence-based corporate crime-control strategy.

Employee and union empowerment to regulate corporate crime is just one variant of civil society empowerment to check regulatory capture and corruption by state regulators (Ayres and Braithwaite 1992: Ch. 3). Ayres and Braithwaite argue that it might not be so critical whether the third party that checks police corruption in the regulation of sex work is a sex workers' union, a feminist group or a religious group. If any or all of these have sight into regulatory encounters, shady deals and the re-emergence of modern slavery are at risk of being exposed. Obviously, environmental 
groups play a critical role here in tempering the abuse of environmental laws, as do consumer groups with consumer laws and shareholders' associations with securities laws. Ayres and Braithwaite (1992) said that secrecy and indirect victimisation made it hard for civil society scrutiny to work for the capture of tax authorities by the big end of town. Yet today Citizens for Tax Justice and Oxfam, among other organisations concerned with tax equity, do just this. And there is little doubt that some of their highest-profile targets, like Google and Facebook, are paying much more tax in many countries as a result of their campaigns and scrutiny (Dyreng et al. 2016; van der Walt forthcoming).

What old and new analyses-from microcorporate practices of separated corporate roles of receiving and paying accounts, separated roles of unions and management to separated roles of civil society and state regulatorshave in common is an understanding of the principle of variegation in separations of powers. We can conceptually ratchet this up a notch to the institutionalisation of separations of powers. Unfortunately, we see a wide gap between what we learn inductively from waves of white-collar crime and institutional abstractions about the separation of powers in legal theory. These legal theory insights are derived from the thought of Montesquieu. The separations of powers described above for the prevention of white-collar crime must be continually adapting to counterstrategy dynamics (Cohen and Machalek 1988). Astute readers will have guessed what I am driving at here: stronger families, schools, welfare and religious institutions, as discussed by Messner and Rosenfeld, will hardly be enough to institutionalise the tempering of criminal power on Wall Street. That is not to say that some virtues instilled by good mothers and fathers, good schools and ethical religious leaders might not help to civilise markets. They really might. What is also needed is separations of political and legal powers that cut with rather deep specificity into structures of avarice. This is missing, or at best out of balance, in the writing of Messner and Rosenfeld (2013).

At a higher level of abstraction, the next chapter addresses the need for strong financial capital to be checked by strong human capital, social capital, recovery capital and restorative capital. This, in turn, is taken up another notch in abstraction in Chapter 8 to an ideology and an institutionalisation of strong markets, strong states, strong civil society and strong individuals each tempering the power of the other. Finally, the book seeks to retheorise institutional anomie theory as requiring state and nonstate institutions that are strong on provision (the welfare state, the 
infrastructure state), strong on redistribution (tax policy, multilateral aid policies that create opportunities for poor people in poor countries) and strong on regulation. Both nonstate and state institutions bake cakes, slice them and regulate the processes of baking and slicing. None of these roles of institutions should be neglected in the politics of institutional design. These are abstractions that assist rethinking towards a more ambitious version of institutional anomie theory in this book.

\section{Neglect of concentrations of private power}

The separation of powers may be the most central idea in the theory of institutional design, yet this is only true of thinking about public institutions. This chapter extends the relevance of the doctrine into thinking about checking the power of private institutions. The practice of separating powers dates at least from the ancient Babylonian Code of Hammurabi, when laws were carved in literal stone that would constrain the actions not only of subjects but also of the king. There follows a more or less cumulative history of the separation of powers sedimented in the institutions of contemporary democracies as commanding-heights institutions became larger with more complex divisions of labour.

Among the important moments in this history were the mixed Spartan Constitution, the Roman Senate and Justinian's Code, Magna Carta, the jury, the rise of judicial independence, bicameral parliaments, professional journalism as a fourth estate and the growth of universities as accumulators and communicators of knowledge. These decisively important institutions of ideas called universities became progressively more independent of church and state until national security states and corporate power came to see it as important to deeply penetrate universities.

Notwithstanding the important contributions of John Locke (1960) and other Enlightenment scholars, the practice of the separation of powers was ahead of the theory until Montesquieu published The Spirit of the Laws. The richest development of these ideas flowed from the debates between the federalists (Hamilton et al. 1963) and antifederalists (Ketcham 1986) in the drafting of the US Constitution. The political philosophies of both the federalists and the antifederalists were republican. Philip Pettit has been the primary inspiration in a program of work at The Australian 
National University and Princeton University to excavate the foundations of the republican approach to the tempering of power as a commitment to freedom as nondomination (Braithwaite and Pettit 1990; Pettit 1997, $2012,2014)$. In that work, checking power under a rule of law designed to minimise the capacity of others to exercise arbitrary power over us is seen as the keystone of the freedom republicans cherish. While the republican theorising and constitution-writing of the late eighteenth century clarified thinking about the separation of powers, their legacy was also to constrict vigilance to narrow checking of state power.

State despotism and autocracy were seen as threats to our freedom. As a result, when we think of the separation of powers today, we think of the separation of these branches of the state: the legislature, the executive and the judiciary. Yet equally important in the history of the separation of powers has been the separation of church and state. More important in terms of contemporary structures of domination is the separation of business and the state. For many decades now, the 50 largest global corporations all have had greater resources, stronger global political connections and more practical coercive capabilities than most of the world's states (Barnet and Cavanagh 1994).

The technology that monitors all our financial transactions, the tracing of our movements about a city, the things we do in the most private spaces of the metropolis-all are captured digitally not by the state tyrant that George Orwell (1949) feared, but by private platforms and nodes of power. This is not just about platforms like Facebook and its Chinese equivalents. It is also about privatised intelligence organisations like Lockheed Martin (the largest of them) that are asked to do some of the street-level intelligence work that states find too sensitive to do. The legacy of the republican tradition is an obsession with the powers of state police in societies with twice as many private as public police (Shearing and Stenning 1987). For societies like Australia, Rupert Murdoch has more influence over the Prime Minister and Cabinet than any member of the judiciary. Moreover, that is only a tiny part of Murdoch's power compared with the influence he has in the United States and beyond. Through influence in several states, such private actors sometimes shape global regulatory regimes in ways that make the citizens of all states subservient to them. 
Today, therefore, the separation of business and state has an importance that the separation of church and state and the separation of powers within the state once had. Even more neglected in the scholarly literature, however, is the separation of powers within business. The major exception is the vast literature on national antitrust and the breakup of global cartels. If the reason we take the separation of powers seriously is the republican concern to protect liberty from domination by concentrations of arbitrary power, the separation of private powers must be of equal importance today to that of state power. One objective of this chapter is to help redress this imbalance in the separation of powers literature by focusing primarily on separations of private powers. This book shows that the different perspective developed on separations of private powers is relevant to public power as well.

The way the need for separations of powers is reconceptualised in this chapter is in terms of certain deep practical difficulties in monitoring and deterring the abuse of power. This book will show why attempts to deter the abuse of power often rebound, making things worse for citizens who suffer abuse. It then shows how innovative separations of powers can ameliorate this. Using research on corporate regulation and selfregulation, the book suggests that the most innovative practice is decades ahead of theory.

One aspiration is to make a minor contribution to republican political theory. Two ideals under that theory are the separation of powers and dialogic democracy-'deliberation in governance in order to shape as well as balance interests (as opposed to deal making between prepolitical interests)' (Sunstein 1988: 1539). Hitherto, these have been regarded as separate desiderata, albeit ones that can be justified in terms of the promotion of freedom as nondomination. A contribution will be to show how the separation of powers nurtures the possibility of deliberative decision-making.

The next section clarifies the reconceptualisation of the separation of powers advanced for consideration and the method by which societies might seek it. Following is a review of an increasingly coherent body of criminological and regulatory theory and data on why attempts to deter the abuse of power with countervailing power evoke defiance and counter-control. The chapter then shows why weak sanctions, especially dialogic ones, generally do better than strong sanctions directed against those who abuse power. Chapter 9 more fully develops the idea that wider 
use of restorative justice can strengthen the power of deterrence when it is deployed. The book argues that weak sanctions are least likely to work when directed against those who benefit from the abuse of power; they are more likely to work when directed against nonbeneficiaries of the abuse who have preventive capabilities.

Then this chapter contends that plural separations of powers both within and between the public and private sectors create the conditions in which deliberative mechanisms to control the abuse of power can flourish. It explains in a little more detail what separations of powers mean within the private sector and sketches some implications of the analysis for the economic efficiency of separations of powers. Tempered power strengthens the power of all branches of governance to perform their functions decisively. The next chapter argues more fully that tempered private and public powers also strengthen the power of markets to function effectively. The conclusion of the chapter is that a plural republican separation of powers is a midwife of deliberative democracy wherein webs of dialogue are more important than webs of coercion to control the abuse of power (Braithwaite and Drahos 2000). Dialogic responsibility among powers with richly pluralised separations means the abuse of power is checked through the process of soft targets simply being persuaded by discussion into accepting accountability for putting things right. Republican dialogue itself is also concluded to be the best guarantee we can hope for to protect us against economically inefficient ways of transacting the separation of powers.

The method in this chapter is not to analyse the history of the idea of the separation of powers. Rather, it is to move inductively towards a reconceptualisation of the idea from: 1 ) an understanding of contemporary practices of separating private and public powers, and 2) the revelations of empirical social science about the difficulties of deterring the abuse of power with countervailing power. At the same time, the method is to move deductively from a republican political theory to a proposed reshaping of the doctrine of the separation of powers.

An analysis of the history of the idea of the separation of powers is of less use to making such a contribution to the theory of institutional design than the abductive ${ }^{1}$ analysis of practices employed here. This is because of

1 Abduction means shuttling backwards and forwards between induction and deduction (see Scheff 1990). 
the limited theoretical coherence of the distinctions that have been made in the great historical contests between the competing, yet related, ideas of the separation of powers, mixed government, balanced government, and checks and balances. A mixing or balancing of powers logically entails a separation of powers, ${ }^{2}$ yet these labels in history are attached to competing concrete programs of institutional reform, and indeed to disparate reform programs in different societies. Moreover, as Vile (1963) showed, the competing reform programs of the separation of powers, mixed and balanced government, and checks and balances have all left their traces. These traces survive in the complex constitutional theories that are the contemporary inheritance of these contests over the nature of good government.

\section{From Sparta to Madisonian separations of private powers}

Mixed government is the oldest idea, figuring in the writing of Aristotle and Plato and justified in terms of securing moderation rather than excess in government and avoiding arbitrary rule (Plato 1892). The mix in Sparta was between the powers of dual kings (replicated in recent times by transnational corporations such as Philips, which have had dual CEOs) and the Council of Elders and Ephors elected by lot (Vile 1963: 35). During the transition from feudalism to capitalism, the reform program of mixed government involved the king or queen, the lords and the male bourgeoisie sharing power so that no single power would predominate. 'The importance of the ancient theory of mixed government $\ldots$ is its insistence upon the necessity for a number of separate branches of government if arbitrary rule is to be avoided' (Vile 1963: 36). It was not based on a separation of the functions proper to each branch, as each branch was expected to check the arbitrary power of other branches by getting involved in all aspects of government. The mid-seventeenthcentury theory of the balanced constitution was a hybrid of mixed government between king, lords and commoners, and some division of functions among them. ${ }^{3}$ Then, in the late seventeenth century, the

2 One cannot 'mix' or 'balance' powers that are unified; they must first be separated.

3 James Harrington and John Milton were important thinkers on these hybrids, as discussed in Vile (1963: 29-30, 39-40, 98-101). 
American antifederalists embraced a purist conception of the separation of powers that mapped on to a strict division of the functions of executive, legislative and judicial branches (Manin 1994).

The contemporary republican reconceptualisation of the separation of powers suggests the ancients were wise to see the objective of mixed government as the checking of arbitrary power. Historically contingent judgements are then needed about whether arbitrary power will be better checked by associating more or less clearly separated functions with the powers that different branches of governance exercise. Neither a purist commitment to dividing power as strictly as possible among branches that do not interfere in each other's functions nor a purist commitment to empowering all branches to be equally involved in all functions of government will prove attractive if one has the republican objective of checking arbitrary power. Sometimes we will need a strong state to exercise countervailing power against strong private interests, or vice versa. Sometimes we will want to constrain one branch from a kind of interference in the governance of another branch that would completely compromise the latter's capacity for independent action.

International relations theorists of the balance of power have provided useful formulations for republicans who must reject such purisms. Hans Morgenthau (1973: 169) conceptualises the 'balance of power' as

allowing the different elements to pursue their opposing tendencies up to the point where the tendency of one is not so strong as to overcome the tendency of the others, but strong enough to prevent the others from overcoming its own.

While this is useful, Morgenthau is even more myopic than Montesquieu in the powers he sees as contesting the balance. They are unitary nationstates, while for Montesquieu they are limited to the legislative, executive and judicial branches of states. Closer to the position reached here is James Madison's in 'Federalist No. 10' that more rather than fewer factions in a republic provide better protection against domination of our liberty by one faction because of 'the greater security afforded by a greater variety of parties, against the event of any one party being able to outnumber and oppress the rest' (Hamilton et al. 1963: 321). Madison also made passing reference to the importance of separating private powers, 'where the constant aim is to divide and arrange the several offices in such a way that each may be a check on the other' (Hamilton et al. 1963: 320). 
Contrary to Montesquieu, my conclusion will be that it is better to have many less-clear separations of public and private power than a few very clear ones. This is better for freedom, better for crime prevention and better for preventing the criminalisation of states and the criminalisation of markets. The republican canvas Madison sought to paint was more a Jackson Pollock than a Mondrian. The splashed canvas will be one on which private powers will need to be granted some autonomy from state powers and vice versa, yet where private power is able to check public power and vice versa. It will be a canvas on which powers are separated between the private and the public, within the public and within the private spheres, where separations are many and transcend private-public divisions. The ideal is enough independence for one branch of private, public or hybrid governance for it to be able to make its best contribution to advancing republican freedom without being prevented from doing so by the domination of some other branch. The ideal is also enough interdependence for many branches in combination to be able to check the power of one branch from dominating others. I will argue for the ideal of many semi-autonomous powers (Moore 1978) recursively checking one another rather than a few autonomous branches of governance. More richly plural separations into semi-autonomous powers better advance freedom, crime control and flourishing of the economy. Sufficiently plural separations mean that the dependence of each power on many other guardians of power will secure their independence from domination by any one power. In a relational state (Peake and Forsyth forthcoming), there is space for Hannah Arendt's insight that widely enmeshed relationships freely grant power to powerholders who are responsive and nondominating. The embedded autonomy of developmental states in the writing of Evans (1995) is on a similar track here in terms of how to prevent states from becoming predatory.

Just as this conception of separations of powers in the modern world is pluralist about the variety of branches of private and public power that should be involved in pursuing and checking power, so we should be pluralist about what we mean by the nature of the power that is separated. Madison was loose in the way he switched between talking about the power of factions, of parties, of 'the multiplicity of interests', 'the multiplicity of sects', of branches of governance and of guardians. Many kinds of power can be exercised by many kinds of individual and 
collective actors. I perhaps get looser still in arguing for strong markets, strong states, strong civil society and strong individuals that each temper the power of the other.

The character of the powers that are separated will be variable. Sometimes the separated power will be the power of one actor to impose their will on others (Dahl 1957). In other cases, the separated power will be the power to write rules that the writer has no power to enforce (Clegg 1975: 67-75). Some powers will be Lukes' (1974) 'second face' of power: a capacity to keep items off or on the agenda without a need for any imposition of will. Other powers will be Latour's (1986) capacity to enrol others to one's projects without directly imposing one's will on the object of control. Others might be Foucauldian (Foucault 1977) disciplinary networks partially advanced through the practices of agents rather than intended or willed as acts of power. Or they could be Foucauldian shepherds governing, caring for and steering flocks (Garland 1990; Hindess 1996). Separated powers could amount to a Gramscian (1971) hegemony that constitutes individuals who cannot recognise that they are being steered and shaped. The last entry is analytically strategic because the final chapter joins arms with Chantal Mouffe $(2013,2018)$ on agonistic pluralism for renegotiating a reshaping of hegemony. Normatively, what republicans of my stripe want preserved is freedom as nondomination; in different contexts, different types of power exercised by plural agents of power will do that job best. So, one wants such plural separations of disparate modalities of private and public power as will maximise freedom as nondomination. None of this is particularly novel; it is simply a somewhat radicalising extension of tendencies that can be found in the writing of James Madison. Indeed, the idea of inequality and domination as the great drivers of corruption that must be contested by the citizens and institutions of the republic can also be found in Machiavelli's Florentine Histories (Maher 2016).

There are a few reasons Madison and other advocates of the separation of powers found the doctrine attractive. There is the desire to limit the damage that one all-powerful bad ruler can do, to expand the diversity of perspectives that have influence in politics, to foster deliberative democracy by requiring one branch of governance to persuade another that it has exercised its power wisely, to constrain the arbitrariness of power by constraining the rule of men by the rule of law and to empower those who might otherwise be powerless. This book adds to Madison's list the importance of separated powers to the prevention of the criminalisation 
of the state and the criminalisation of corporations and markets. This chapter will not systematically evaluate the desirability or feasibility of all these rationales for the separation of powers. The analysis will focus on a fresh perspective on just one rationale for the separation of powers, albeit one that republicans should regard as the most fundamental: tempering the abuse of power, especially domination and crime by powerful actors.

Before we can reach the point of understanding why pluralities of checks are the reconceptualisation of the separation of powers needed for the contemporary world, we must begin with an understanding of the empirical literature on why efforts to check the abuse of power so often backfire.

\section{Deterrence failure}

The starting point for reaching the conclusions promised is to abstract from what we have learned empirically about the way the regulation of private power works, or rather why it so regularly fails to work. The republican idea of checking power with countervailing power is often read as a deterrence model for controlling the abuse of power. Indeed, deterrence will have an important place in the conclusion ultimately reached in Chapter 9 on tempered deterrence.

This section will first briefly explain why deterrence often does not work well with the crimes of the powerful. Deterrence often backfires and organisational deterrence has a capacity to defeat its own objectives because, for example, of the way powerful corporations can snatch victory from the jaws of defeat by counter-publicity to combat adverse publicity (Fisse and Braithwaite 1983). My argument will be that if we understand these problems properly, separations of powers will prove relevant to their amelioration.

Criminology is the field that has grappled most systematically with why deterrence does not work well. People almost universally value their lives, so it is surprising that introducing capital punishment is not shown to significantly reduce the rate of any kind of crime, and nor does abolishing the death penalty increase it (Bailey and Peterson 1994). It is surprising that building more prisons and locking up more people in them for longer periods do not have predictable effects in substantially reducing the crime rate. We discuss the evidence for this in Chapter 9. It is surprising that 
people who perceive the expected severity of punishment for committing a crime to be high are not more likely to refrain from crime than people who expect the severity of punishment from committing a crime to be low. The evidence for the expected certainty of detection reducing crime is much stronger, as discussed in Chapter 9. The United States, with a death penalty in some states that other developed nations do not have, with more private and public police than they, with imprisonment rates many times higher than the average for wealthy countries, has not the lowest crime rates, but the highest of any of the wealthy nations. How can this be?

One reason discussed in Chapter 9 is that the protection we get from many of the worst crimes is not bound up with calculative deliberation. Rather, the prevention that matters is delivered by institutions that constitute the unthinkableness of murder or burglary for most people. This is a core message of Crime, Shame and Reintegration (Braithwaite 1989; Ahmed et al. 2001). Another reason for corporate deterrence failure is the defiance effect of punishment that can increase crime rather than reduce it. Human emotions turn out to be complex in ways that make people less than rational in their calculations about compliance with laws (Makkai and Braithwaite 1994a). Braithwaite (1997) argued that the limitations of deterrence for organisational crimes are even more profound than for the crimes of individuals. Among the reasons for this are that powerful corporations have well-documented capacities to organise their affairs so no-one can be called to account (Fisse and Braithwaite 1993).

The larger and more powerful the organisation, the more inherently complex and hard to prove are their abuses of power. More than that, complexity is something powerful actors can contrive into their affairs. This includes organisational complexity as to who is responsible for what, jurisdictional complexity as to which state was the site where each element of the offence occurred, the complexity of the accounts and the complexity that 'repeat corporate players' have been able to contrive into the law on previous occasions when they have 'played for rules' as much as played for outcomes. The more punitive a regulatory regime is, the more worthwhile it is for powerful corporations to have 'vice-presidents responsible for going to jail' (Braithwaite 1984). The more powerful the corporate or state actor, the greater is the capability for putting countermeasures in place; the more credible the corporate deterrence, the more reason tyrants have for counter-deterrence. 
This connects to the ideas of a retribution trap and a deterrence trap. The retribution trap is that there is no punishment proportionate to the harm banks do when they cause a financial crisis and a recession, and if there were it might cause another recession; the retribution trap is the risk that the only sanction a people will judge as proportionate to a genocide is a counter-genocide.

Coffee's (1981) 'deterrence trap' is that precisely when the stakes are highest with an abuse of power, the regulator is likely to fall into a deterrence trap because the inherent and contrived complexity associated with the biggest abuses of organisational power mean the probabilities of both detection and conviction fall. Imagine, for example, that the risks of conviction for insider trading are only one in 100 for a corporate stock market player who can afford quality legal advice. Imagine that the average returns to insider trading are $\$ 10$ million. Under a crude expected utility model, it will then be rational for the average insider trader to continue unless the penalty exceeds $\$ 1$ billion. Assume this would be a large enough penalty to bankrupt many medium-sized companies, leaving innocent workers unemployed, creditors unpaid and communities deprived of their financial base. This is what is required to deter the average insider trader under these crude assumptions. But the criminal law cannot be designed to deal simply with the average case. It should be designed so it can deter the worst cases, which, with sophisticated corporate crime, involve not millions, but billions. Here, the deterrence trap seems inescapably deep. These problems are further compounded with public-sector abuse of power.

This chapter advances two counterintuitive strategies for beating the low detection risks, the defiance, the rational countermeasures and the deterrence traps that make legal checks on the abuse of power difficult at best, and counterproductive at worst:

1. Replace narrow, formal and strongly punitive responsibility (the 'find the crook' strategy) with broad, informal, weak sanctions.

2. Separate enforcement targeting from identification of the actor who benefits from the abuse of power.

It argues that at the macrolevel of the polity, these strategies depend on plural separations of powers both within and between the public and private sectors. 


\section{The strength of weak sanctions}

The above two strategies for beating defiance, and counter-publicity, scapegoating, contrived complexity and other counterstrategies enabled by corporate power rely on an obvious fact about the abuse of power: the more serious the abuse, the more likely it is that many people will be involved. The most egregious abuses of power arise when whole armies, police forces, bureaucracies or global corporations can be mobilised to execute exploitative conduct. Fisse and Braithwaite (1993) concluded from their various empirical studies that a feature of corporate crime is that it is overdetermined, as the philosophers say, by the acts and omissions of many individuals, organisations and subunits of organisations. While only a small number of people may be involved in committing a corporate crime, our empirical work shows that a much larger number usually have the power to prevent it. These people vary in the degree they care about the conduct being regulated and, therefore, in their susceptibility to defiance and deterrence.

This also means their susceptibility to what Christine Parker (2006) calls the compliance trap: deterrence failure because of failure to address perceptions inside organisations of the morality of regulated behaviour. The compliance trap is a defiance trap in that a regulator's messages induce defiance, undercut intrinsic motivation for compliance and ultimately threaten political support for the regulatory institution.

One fresh approach in the literature for responding to the compliance trap is to marry responsive regulation to Tversky and Kahneman's (1981) framing effects for perceptions inside organisations. Netta BarakCorren (2021) found that reframing regulatory mandates as affirming organisational subcultures, leaving organisational cultures unchallenged (but actually adding some value to them), substantially increased compliance, most strongly so among the most conservative opponents of regulatory values. Whether this is a good approach normatively will depend on how much of organisational subcultures can be affirmed as opening doors to non-domination. The most macro approach to tempering the form of power manifest in the compliance trap throughout this book is radical redesign of democracy to temper anomie and dampen legal cynicism. The I for Identity in CHIME is an important part of the freedom theory of crime prevention for Barak-Corren's identity threat analysis of the compliance trap. Part of this that is particularly important 
to responsiveness to the compliance trap is outside-in regulatory design that involves active deliberation with business and civil society, rather than inside-out regulatory design dominated by the state. This in turn is enabled by the enculturation of trust combined with the instiutionalisation of distrust. Restorative justice deliberation at the base of regulatory pyramids combined with escalation of deliberative supports alongside punitive escalations up the pyramid is, I will argue, another remedy to the compliance trap. One reason is that the responsive regulatory strategy thereby nurtures intrinsic motivation to comply by being circumspect about extrinsic approaches that crowd out intrinsic motivation to comply. The evidence has grown that motivational interviewing is a helpful micro competence in soft skills that can be trained for persuading personal and organisational reform. It is particularly helpful for getting agreement, I will argue, that prosecution for a future offence would be fair after prosecution is deferred for a current offence. Finally, the book argues that widening restorative justice circles when every participant in a first circle is defiant can escape the compliance trap by widening the circle until an organisational actor is found with the will and the power to prevent reoffending.

It may be that rational actors need a billion-dollar fine if they are to be deterred from insider trading from which they benefit. But they, the beneficiary(ies) of the crime, are not the only potential deterrence targets. They may have a boss; their boss may have a boss who is able to stop the misconduct. They may have a variety of subordinates who can prevent the wrongdoing by exposing the crime or failing to execute some critical component of it. A secretary or executive assistant, for example, who is privy to information, frequently does the 'whistleblowing' that lands their employer in jail for major fraud. Then there are auditors, law firms, consultants, investment bankers, suppliers and buyers upstream and downstream who know what is going on in the criminal organisation. Most of these actors may spurn the morality of those who seek to regulate them, but some may share the morality of the regulators or of the community that is protected by the regulation. Hence, Fisse and Braithwaite (1993: 220) concluded:

In a complex corporate offence there can be three types of actors who bear some level of responsibility for the wrongdoing or capacity to prevent the wrongdoing: 
1. hard targets who cannot be deterred by maximum penalties provided in the law;

2. vulnerable targets who can be deterred by maximum penalties; and

3. soft targets who can be deterred by a sense of responsibility, by shame, by the mere exposure of the fact that they have failed to meet some responsibility they bear, even if that is not a matter of criminal responsibility.

The organisational crime literature has revealed several ways of exploiting the possibility that there are many enforcement targets beyond the primary perpetrators and primary beneficiaries of the crime. One is the strategy mentioned earlier. You grab a minor member of the major perpetrator's team and accuse them of some much more minor illegality around which secrecy is not so tightly guarded. This charge may then be dropped after the defendant gives up a more senior member of the team for matters more serious. These gotcha moments move up a hierarchy of seriousness to the major corporate crime. Along the journey of the regulator and the prosecutor kicking the corporate tyres initially on more minor regulatory offences, and long before reaching billion-dollar criminals, experience with corporate crime investigations shows that the board of directors becomes concerned and tends to start finding its own perpetrators, firing them, demoting them and introducing compliance reforms. Waldman (1978) was the first to show systematically that with corporate crime most deterrence and prevention precede rather than follow conviction. The overdetermined organisational form of corporate crime makes the dynamics of deterrence totally different from that with individual crime in this respect.

Compliance remediation to pre-empt sanctions is well-documented in empirical studies of enforcement cases en route to court. Of Fisse and Braithwaite's (1983) case studies of corporations that had been through major adverse publicity scandals over corporate offences, only five suffered criminal prosecutions and few suffered significant financial impacts from the adverse publicity. Yet every one of them implemented some worthwhile reform in response to the crisis, and some implemented major reforms. Waldman's (1978) neglected study of the impact of antitrust prosecutions found that some of the most positive changes in the competitiveness of markets came in cases that prosecutors lost. Waldman, like Fisse and Braithwaite, found systematic pre-emptive deterrence and reform effects in their empirical work. While an antitrust prosecution is incubating 
(often for years), defendant companies find that one of the best ways to defend themselves in court, or to get the case dropped, is to improve the competitiveness of their behaviour. As it awaits trial, the firm sometimes pulls down barriers to entry to the industry that it had erected. It may cease retaliating against weaker competitors (as in predatory pricing). It sometimes even eschews monopoly by actively inviting a competitor into the industry and in other cases breaks up monopoly by divesting itself of part of its business in advance of a trial. And it very commonly improved antitrust compliance policies and fired executives responsible for past misconduct, all in the cause of winning or dealing with its big case (Waldman 1978). Karpoff et al. (2008a) found in 585 US Securities and Exchange Commission (SEC) cases that 92 per cent of managers identified by the SEC as responsible for financial misrepresentation lost their job-81 per cent of them before the SEC imposed any formal sanctions.

Put another way, most specific deterrence effects precede corporate sentencing, precede trial and, as our nursing home inspection data demonstrate (Braithwaite et al. 2007), can even precede the arrival of the inspector at the front door. As Fisse and Braithwaite (1983: 243) concluded from their empirical study: 'When a company is struck by publicity concerning an alleged crime, it typically implements reform measures to persuade the government against following the publicity with a prosecution.' This book reinforces Marsavelski and Braithwaite's (2018) findings that complex war crimes trials define another domain where prosecutors have been shown to use the 'gotcha' strategy of moving from small fish to ever-larger sharks. It is hard to exterminate a large number of people by shooting without many people being involved in the killing, in the transmission of the orders to shoot, in transport and logistics and in simply standing by watching it happen. The risk that someone hiding behind a tree is filming the killing on their phone has also grown in a world of most citizens having a movie camera in their pocket. This multiplies the opportunities to mobilise this strategy.

A second strategy that worked by putting regulatory pressure on targets who were not the primary beneficiaries of the corporate crime was Stanley Sporkin's innovations as Director of Enforcement for the SEC in the 1970s when he lifted the lid on the foreign bribery scandals. Fisse and Braithwaite (1983) interviewed Sporkin and very senior executives in the companies involved like Lockheed, Exxon, McDonnell-Douglas, General Dynamics, IT\&T, General Motors, Ford and most US Big Pharma 
corporations. The huge early case was Lockheed, which was paying bribes to top officials in many countries to sell aircraft. Among them were Prime Minister Tanaka of Japan and Netherlands Defence Minister Prince Bernhard. Sporkin asked all companies to make fulsome and systematic voluntary disclosures of their questionable foreign payments if they wanted to avoid criminal prosecution. So, who cracked at Lockheed to open this can of worms? It was their external auditor, the firm Arthur Young (Boulton 1978: 276). Arthur Young was a targeted gatekeeper rather than a perpetrator (Kraakman 1984). By refusing to let Lockheed's annual report through the gate it guarded, Arthur Young brought Lockheed's bribery of defence ministers and heads of state to an end, not to mention the careers of the company's chairman and president. Large corporations have many kinds of gatekeepers, such as the general counsel, environmental auditors, insurers, board audit or ethics committees, and occupational health and safety committees. Each has the power to open and close gates that give the organisation access to things it wants.

A gatekeeper like Arthur Young surely had an interest in doing Lockheed's bidding so it could keep the Lockheed account. Yet Arthur Young was much more deterrable than Lockheed itself, which benefited so directly from the bribery (as did Lockheed's top management). Arthur Young, as a nonbeneficiary of the bribes, had less to lose from stopping them; as a gatekeeper that was not responsible for paying bribes, but only for failing to detect them, it also had less to lose from the truth than did those who were handing over the cash. Yet it had much to lose in reputational capital as a gatekeeper of hundreds of other corporate clients if someone else revealed the truth. In this case, they were the comparatively soft target which felt compelled to sound an alarm that led to the demise of some of the hardest targets one could find in the world at that time, such as Prime Minister Tanaka.

Economists', lawyers' and criminologists' intuitions alike tend to be that the state should design enforcement systems to target the beneficiaries of wrongdoing. They are the actors who make the criminal choice based on the benefits of lawbreaking exceeding its costs. From a simple rational choice perspective, we should target the increased costs of lawbreaking on them, those choosing criminals, not on their guardians. The flipping of Arthur Young triggered an enormously consequential cascade. Hundreds of companies rushed to beat their accountants to the SEC to disclose bribes that the SEC allowed them to describe as 'questionable payments'. Thousands of executives were fired or disciplined by boards concerned to 
pre-empt external criminal enforcement. Prime Minister Tanaka, leader of the second-most powerful country at the time, resigned before he was dismissed; Prince Bernard, from one of the remaining influential royal families in Europe, resigned as defence minister before he was pushed. This led in turn to a cascade of resignations of many top government officials in many countries who had taken bribes from major US corporations. The United States then legislated for the Foreign Corrupt Practices Act. The US elite was concerned that the Act would make its firms less competitive against foreign competitors that were still wantonly paying bribes.

US diplomats successfully lobbied for a globalisation of the prohibitions and enforcement strategies in the Foreign Corrupt Practices Act. A law reform cascade as well as a global enforcement cascade and a resignation and reform cascade were triggered past a tipping point by an American accounting firm that was a soft target that had done nothing worse than being a careless gatekeeper.

Another empirical demonstration of the power of targeting gatekeepers rather than beneficiaries of the wrongdoing came from the most global of regulatory problems: pollution from ships at sea. Ronald Mitchell (1994a, 1994b) demonstrated how the International Convention for the Prevention of Pollution from Ships was an utter failure. Signatories were required under the convention to impose penalties for intentional oil spills. The most important targets, petroleum-exporting nations, were committed to not enforcing these laws. Most states simply did not care to invest in proving offences that were difficult to detect. Only a few petroleum-importing nations took the requirement seriously. This meant ships had simply to be a little careful to discharge pollution outside the territorial waters of these few countries. Noncompliance with the regime was the norm.

Then in 1980 the oil spill regime was reformed in a way that Mitchell (1994a: 270-71) estimates generated 98 per cent compliance. This was a remarkable accomplishment given the costs of compliance with the new regime were high for ship owners, and given that predictions grounded in the economic analysis of regulation were for minimal compliance. The key change was a move away from the imposition of penalties on ships responsible for spills to an equipment sub-regime that enforced the installation of segregated ballast tanks and crude oil washing. One reason for the improvement was transparency; it was easy to check whether a tanker had segregated ballast tanks, but hard to catch 
it discharging at sea. The other critical factor was the role of third-party enforcers: a) on whom ship operators are dependent, and b) who have no economic interest in avoiding the considerable costs of the regulation. These third-party enforcers were shipbuilders, classification societies and insurance companies. Shipbuilders had no interest in building cheaper ships that would not get certification by international classification societies nominated by national governments. Classification societies had no interest in corrupting the standards they enforced, which were the whole reason for the generation of their income. Finally, insurers would not insure ships that had not been passed by a classification society acceptable to them because they had an interest in reducing the liabilities that might arise from oil spills.

The revised regime therefore achieved 98 per cent compliance in large part because the effective targets of enforcement shifted from the ship operators that benefited from the pollution to shipbuilders, classification societies and insurance companies which did not benefit. However, because the ship operators (and builders) were totally dependent on classification societies and insurers, operators had no choice but to insist on regime-compliant ships, which the classification societies had an interest in ensuring were the only ones that got through their gatekeeper's gate.

The best-known examples of separating enforcement targeting from the actor who benefits from the abuse is requiring employers to withhold tax from the taxable income of their employees, or banks withholding and/or reporting tax payments on the interest earned by their customers. Little enforcement is needed against the employers and banks that withhold and report because they do not benefit from any underreporting of income. Tax cheating is only a major problem in those domains where it is impossible to harness such disinterested gatekeepers. These withholding policies have possibly counted among the most successful crime-control policies of our time.

Peter Grabosky (1990a, 1990b, 1992, 1994a, 1994b, 1995a, 1995b, 2017) pursued a program of work that continuously discovered new species of third-party enforcers of regulatory regimes-from volunteer divers who check compliance with South Australia's historical shipwrecks legislation to elected worker health and safety representatives. Note the good governance efficiency in the fact that divers and workers have natural, frequent lines of sight to locales of criminality as they do what they normally do. Grabosky's work showed just how disparate are the 
possibilities for shifting enforcement targeting-from actors who benefit from the cheating to actors who do not but on whom the cheat depends for something critical to their welfare. This simple shift can make headway with some of our seemingly most intractable law enforcement challenges.

Grabosky's Smart Regulation (Gunningham and Grabosky 1998) co-author, Neil Gunningham, long despaired about the way hazardous chemicals regulation succeeded in changing the practices of the top20 global chemical corporations, but barely touched thousands of little chemical companies which were too numerous, too unsophisticated and too dispersed to be effectively supervised by state inspectors. Worse, the major chemical companies often spin off their most hazardous activities upstream or downstream to fungible contractors. Eventually, Gunningham realised that most of these small chemical companies are dependent on global chemical firms as suppliers, distributors, customers or all three. This led Gunningham (1995) to the insight that a private or public regulatory regime that requires major companies to ensure not only that their own employees comply with the regulations, but also that the upstream and downstream users and suppliers of their products comply may massively increase its effectiveness. The reason is that a global firm that supplies a little chemical company has much more regular contact with them than any government inspector, more intimate and technically sophisticated knowledge of where their bodies are buried, greater technical capacity to help them fix the problems and more leverage over them than the state. Often, they get to know what is going on because of explicit auditing practices that put them in a better position to regulate malpractice than any government regulator. For example, in analysing the implications of the chemical industry's 'Responsible Care' program, Gunningham explained:

Dow insists on conducting an audit before it agrees to supply a new customer with hazardous material, and routinely audits its distributors. The audit involves a team visiting the distributor's operations to examine handling, transportation, storage and terminating techniques and prescribing improvements aimed at achieving environmental standards far in advance of current regulatory requirements. Many large chemical manufacturers go further. (Gunningham 1996) 


\section{Building a thousand gates to the power of corrupt officials}

Privatising public gatekeeping can be one way of separating powers so that enforcement can be targeted on an actor who does not benefit from the abuse of public power. Many national customs services have a lot of corruption. Both senior managers and street-level bureaucrats benefit from bribes paid for turning a blind eye to the under or over-invoicing of goods. The fact that public customs services have an organisational interest in continuing to sell favours creates a market opportunity for a private organisation set up to 'sell trust'. This is just what the Swiss company Société Générale de Surveillance (SGS) set out to do when it took over the customs services of Indonesia and other developing countries. It persuaded nations to contract large parts of their customs work to SGS through its reputation for incorruptibility, which enabled it to deliver huge savings to governments. The Indonesian Government claimed SGS saved it tens of billions of dollars. Because testimonials of this kind from major states bring SGS business, SGS has a financial incentive to catch cheats and weed out corruption in its own ranks. A major corruption scandal that would strike everyone as quite normal in the customs service of a developing country might cause financial ruin for SGS. SGS set up its inspection gates in the country of export (where superior intelligence on over-invoicing or under-invoicing was available) rather than in the importing country. It accomplished this by having more than 1,000 scrupulously audited offices at all the world's key exporting sites. The company constrained itself from engaging in any manufacturing or in any trading or financial interests that would threaten its independence.

'Selling trust' is profitable, so operatives are well paid. As the company's Senior Vice President, J. Friedrich Sauerlander, confessed to me in the 1990 s, in an organisation of 27,000 people (which had grown to 94,000 in 2020), his internal security organisation had uncovered 'some slipups'. But, in the ways that mattered most, it had been possible to sustain an organisation with an incentive structure that rewarded trust. The beneficiaries of the old breaches of trust were left where they were, but through building 1,000 gates to their power on the other side of the world and guarding those gates with SGS units that flourished in proportion to how much abuse of trust they stopped, targeting enforcement on the bad guys inside the gates became mostly redundant. 
From Lockheed to polluters from ships, from employers and banks withholding tax to chemical companies and outside (instead of inside) directors targeted by public interest groups over corporate abuse of power, ${ }^{4}$ we can see some promise in shifting enforcement targeting from actors who benefit from their abuse to actors who do not benefit but on whom the abuser depends for something critical to their welfare.

A third strategy for enforcement that works by hitting soft rather than hard targets is restorative justice. Fisse and Braithwaite (1993) and Parker (2004) described the early restorative justice innovations of the Australian Competition and Consumer Commission (ACCC). This was a strategy of sitting responsible managers down in a restorative circle-preferably one involving victims of the corporate crime-in which the responsible executives were given the opportunity to admit responsibility, apologise to victims, offer compensation and responsive corporate reform and leadership in industry-wide campaigns, even for global self-regulatory reforms. Frequently in ACCC restorative enforcement practice, this did not happen in the first circle. The reason was simple. The commission asked for a meeting with the managers who they believed were criminally responsible for the offence. These managers had the strongest interest in denial within the organisation. Their lawyer who sat beside them also had some interest in failure of the restorative circle and escalation to a criminal prosecution that they might fight and win for the company, thereby earning more fees. After the first circle failed, instead of saying we will see you in court, the ACCC would say it was disappointed the managers did not want to put the injustice right, so let us adjourn this meeting and go away to reflect on our positions. Then the commission would call the boss of those responsible executives to say how disappointed it was that the firm did not want to put the injustice right in the restorative circle and ask the boss to attend a reconvened meeting. Often when that circle was convened the boss turned out to be a tougher nut in resisting formal admissions of responsibility than the directly responsible executives. The ACCC then moved up to another circle with the boss of the boss, then the CEO and in one case even the chair of the board. In that case, the chair was shocked that his CEO should resist a reasonable approach from a respected government regulator to put a serious fraud right voluntarily

4 A germinal example here was the 'Corporate Campaign' against the J.P. Stevens corporation over its abusive labour practices. The top management team were very hard nuts, but the campaign was able to so embarrass external directors that they resigned from the board-a consequence that really did concern top management (see Fisse and Braithwaite 1983: Ch. 2). 
rather than contest the wrongdoing in court. He fired the CEO (not very restorative perhaps), voluntarily paid millions of dollars in compensation to victims of the fraud for a case for which the commission believed, had it won, the fine would be less than $\$ 1$ million. The chair also undertook to lead an industry-wide monitoring campaign to detect future frauds of this kind, not only by his own company, but also by all major competitors in this industry.

This third strategy is to widen the circle of targeted harder targets who are rational actors until a softer target is found in the restorative circle who is motivated by a concern to be ethical, who can be touched by shame over fraudulent conduct.

\section{Summarising mixed relational prevention through softer targets}

Hence, this aspect of past work on corporate crime really exposes six strategies that enable the discovery and mobilisation of the preventive power of ethical soft targets inside culpable organisations, be they public or private. One is the 'gotcha' strategy, which we will see is also fundamental to success in prosecutions against powerful war criminals, with smaller fish who give up bigger fish until the law enforcer nets the sharks. The second is Sporkin's strategy of triggering a cascade of selfdisclosure, self-enforcement and reform by inviting the hard targets to beat the soft targets to be first in a race to the regulator's door with voluntary disclosure of wrongdoing. The third is a restorative strategy of widening the circle of hard targets until a more senior soft target enters the circle and cascades responsible reform right down the organisation and right across an industry. The fourth is relevant to all the first three strategies: it is to exploit the fact that firms will do better in court if they repair harm and discipline responsible executives in advance of a trial. A consequential fifth strategy is qui tam that encourages those without personal responsibility with a bounty payment to beat those with responsibility to the prosecutor's door to disclose the crime (Dukes et al. 2014: Ch. 10). Evidence for the effectiveness of whistleblower bounties is particularly strong with cartel enforcement (Coffee 2020: 81). The healthcare industry is where False Claims Act payouts are most common and highest. Dyck et al. (2010) concluded that the probability of fraud detection in healthcare became three times as high compared with other 
industries in which large False Claims Act bounty payouts were not offered to whistleblowers. It has also worked well with tax enforcement in the United States (Ventry 2014; Wilde 2017; Johannesen and Stolper 2017; Amir et al. 2018; Masclet et al. 2019). This fifth qui tam strategy exploits the reality that many insiders are likely to know about complex organisational crimes, while few or no outsiders do. So, the essence of this strategy is to change the incentive structure to one where those who blow the whistle with their insider knowledge get large financial bounties. This is needed because without it, whistleblowers are punished by ending their careers and ruining their lives. This whistleblower bounty strategy also connects back to Sporkin's second strategy because it motivates a race among whistleblowers to get the reward by being the first to report the crime to the regulator, and it motivates management to beat the whistleblowers to the regulator with a voluntary disclosure.

Coffee (2020) has advocated further development of some incipient privatisation of corporate crime prosecutions by public prosecutors contracting top private law firms with a contingency fee for two to five-year campaigns to take on massively complex corporate crimes. This may be another privatisation that would reduce domination and increase freedom. Coffee (2020) probably rightly believes that to make this work corporate financial penalties need to be hiked in ways that will not bankrupt firms. The solution is equity fines, so that up to 20 per cent of shares in a criminalised corporation would be issued as new shares to a crime victim compensation fund. A reason Coffee may be right is that, structurally, the problem of modern corporate crime is one of criminalised markets. Extreme levels of executive compensation are on offer for managers who are encouraged to take extreme risks with the criminal law (Coffee 2020: x).

A sixth strategy that is relevant to all five foregoing strategies is to rely on the preventive work of street-level regulatory bureaucrats (Lipsky 2010) more than on the courts. This strategy also applies to policing individual street crimes. We know that if police are deployed to hotspots of individual crime, even if they make no moves towards arresting anyone, they can deter or prevent crime, and potently so (Sherman et al. 1989; Sherman 1995; Ariel et al. 2016). Likewise, the seemingly passive deployment of peacekeepers at hotspots can protect civilians, prevent war crimes and 


\section{prevent war (Braithwaite and D'Costa 2018). ${ }^{5}$ We say passive deployment of peacekeepers, but we really know little empirically about what these peacekeepers do and say on the ground when they have these passive}

5 War recidivism is high: of 108 countries that experienced civil war between 1946 and 2017, only 27 per cent avoided a return to war (Walter et al. 2020: 7). While peacekeeping is well known to have failed catastrophically to prevent war crimes in various cases like Rwanda, the statistical impact across all cases is of effectiveness. Collier's (2009: 96) program of empirical research concluded that US\$100 million spent on UN peacekeepers reduced the cumulative 10-year risk of reversion to conflict from 38 per cent to 17 per cent. That risk falls further, to 13 per cent, if the investment in peacekeeping is scaled up to US $\$ 200$ million. Collier's team presented his conclusions on the benefits and costs for the world economy of investment in peacekeeping to a panel of Nobel Laureate economists for the Copenhagen Consensus. This involved 10 rival research teams making a case for international public money to be spent on something. The Copenhagen Consensus panel's verdict selected peacekeeping as one of their endorsed public expenditures. Doyle and Sambanis (2006: 336) found that the greater effectiveness of a combination of treaties and transformational UN peacebuilding is particularly dramatic when local peacebuilding resources and capacities are low. In a follow-up of these data, Sambanis (2008: 23) found that UN peace operations reduce the risk of peace failure in the longer run by about 50 per cent, as did Fortna (2008). Quinn et al. (2007: 187) found the combination of a treaty and a peace operation reduced the probability of civil war recurrence by 54 per cent. These peace impacts persist after peacekeepers leave. Doyle and Sambanis (2006: 336) found that, without a treaty and UN mission, the statistical prospects of successful peacebuilding in states of low capacity are extremely dim. Many other studies confirm a big statistical contribution of peace operations to building peace (Call 2012; Doyle and Sambanis 2000; Fortna 2003, 2008; Fortna and Howard 2008: 288-94; Gilligan and Sergenti 2008; Hultman et al. 2013; Nilsson 2006; Quinn et al. 2007; Riordan 2013; Sambanis 2008; Walter 2002). Fortna $(2003,2008)$ also found a large tendency for ceasefires overseen by international peacekeepers to be more effective than those without peacekeepers. Hampson (1996) argues that peace agreements are not self-executing: sustained third-party leadership, mediation, problem-solving and peacebuilding are needed as cement to hold the peace together. The wars that are more intractable and serious are the ones that attract the investment in a UN peace operation. Fortna's (2008) systematic quantitative data confirm this. When Gilligan and Sergenti (2008) corrected for the effects of non-random assignment with matching techniques, they found that the causal effect of UN peace operations in preventing war was even larger than would have been estimated had there been no correction for non-random assignment of UN missions. Walter et al. (2020) have completed the most systematic review of this evidence, while in addition showing that the mere promise that peacekeepers will arrive can dampen violence and encourage mediation and the signing of peace agreements: 'What is most striking about these studies is the consistency of their findings. Almost all of them find that peacekeeping is highly effective at preventing violence before it begins, reducing violence in the midst of war and preventing violence from recurring once it has ended. All else [being] equal, countries and regions that receive peacekeeping missions experience less armed conflict, fewer civilian and combatant deaths, fewer mass killings, longer periods of post-conflict peace and fewer repeat wars than those that do not receive peacekeepers. This relationship - between peacekeeping and lower levels of violence-is so consistent across large-n analyses that it has become one of the strongest findings in the international relations literature to date. The power of peacekeeping is all the more striking given that the UN tends to intervene in the toughest cases. Multiple scholarly studies have found that the UN Security Council tends to send peacekeepers to countries with more violence, particularly bad governments and ongoing conflict' (Walter et al. 2020: 2). On the other hand, the United Nations does not send peacekeepers to countries that refuse to accept a UN peace operation, and this is a methodological bias that cuts in the opposite direction. Moreover, countries that received peacekeepers during the past three decades almost always received UN human rights, gender rights and child protection staff; they received UN humanitarian assistance, housing for refugees, economic development, good governance, policing and security sector reform assistance, rolled into a peace operation package. Hence, it might be that what Walter et al.'s (2020) impressive and persuasive review demonstrates is the effectiveness not so much of peacekeepers, but of peace operations, especially $\mathrm{UN}$ ones, in preventing not only war, but also crime. 
preventive effects at hotspots of conflict. In my limited observations of this kind of peacekeeping in these contexts, they do ask people to calm down when shouting starts; they do position themselves between fighters with weapons and the victims they might be interested in shooting; they do raise their eyebrows or gently raise their hand when people behave provocatively; they do enrol local respected religious leaders and ask them to help calm people; and they do set a calming example by 'acting like they are on vacation', ${ }^{6}$ smiling back with gentle understanding at people who shout at them.

When peacekeepers or police act aggressively, however, that can make things worse- a lot worse - as we discuss in Chapter 9 with the violence that cascaded from the police bashing of Rodney King in 1992 and the killing of George Floyd in 2020. Spending more resources on policing can make crime worse when a broken-windows philosophy of arresting disadvantaged people for minor incivilities such as public urination can cause unemployment and contribute to the reproduction of inequality in the society. Spending on police can make crime worse when policing is stigmatising rather than reintegrative (Braithwaite 2002).

With business regulation, we have much more systematic ethnographic data on how street-level inspectors prevent violations of the law. Based on observations of 157 inspections and many other kinds of regulatory encounters in aged care homes in Australia, the United States, the United Kingdom, Canada and Japan, Braithwaite et al. (2007) revealed empirically no fewer than 27 strategies (in Table 6.1) that mainly were deployed through the guardianship work of soft corporate targets. Scholz and Gray (1990) showed that US Occupational Safety and Health Administration (OSHA) inspections contributed significantly to improving corporate compliance at a time when the average expected punishment cost of an OSHA offence could be measured in cents rather than dollars (because of low penalties, infrequent inspections and low detection probabilities). How could that be? How could it be rational to take any notice of an OSHA inspector when expected punishment costs were near zero? Surely firms should just wait for the unlikely occurrence of detection and then write a cheque? One reason inspection worked was that regulatory

6 Thanks to Clifford Shearing, who is the original source for this. For examples of it in peacekeeping in Timor-Leste, see Braithwaite et al. (2012). 
inspection often delivered not by punishing people, but by reminding ethical people of their obligations to do things they knew they should do. Astute inspectors energised them to prioritise properly.

Our observational study of nursing home regulation in all Australian states, 30 US states and across the United Kingdom systematically revealed the 27 mechanisms in Table 6.1 through which regulatory inspection frequently enough had positive effects on compliance with the law. This helps us to see that organisational compliance with the law is achieved not only by impacting many soft targets, but also by impacting them at street level through many different mechanisms. This is how a combination of many mechanisms that are thin reeds can be woven together and deployed against many who are rarely criminal actors to prevent corporate crime more effectively than the single brittle reed of a prosecution.

\section{Table 6.1 Strategies that improved nursing home compliance in certain observed contexts}

\begin{tabular}{|c|c|}
\hline Strategy & Process \\
\hline Reminds & $\begin{array}{l}\text { Tapping a staff member on the shoulder reminds of an } \\
\text { obligation believed in but lost sight of. }\end{array}$ \\
\hline Commits & $\begin{array}{l}\text { Persuading someone who was not persuaded that } \\
\text { compliance would benefit residents. }\end{array}$ \\
\hline Shows & $\begin{array}{l}\text { Shows how to do something necessary for compliance that } \\
\text { the person does not know how to do. }\end{array}$ \\
\hline Fixes & $\begin{array}{l}\text { Inspector fixes something themselves (e.g. releases a } \\
\text { restrained resident). }\end{array}$ \\
\hline Incapacitates individual & $\begin{array}{l}\text { Reports a professional to a licensing body that withdraws/ } \\
\text { suspends their licence. }\end{array}$ \\
\hline Incapacitates home & Withdraws/suspends licence for home. \\
\hline Protects future residents & Bans new admissions until problem is fixed. \\
\hline Management change & $\begin{array}{l}\text { Orchestrates sale or management takeover of the home by } \\
\text { signalling escalation up a regulatory pyramid. }\end{array}$ \\
\hline Shames & Disapproves of noncompliance. \\
\hline Exposes & $\begin{array}{l}\text { Reports noncompliance to the public on a website or the } \\
\text { nursing home notice board, inducing reputational discipline } \\
\text { or market discipline, or both. }\end{array}$ \\
\hline Praises & Congratulates improvement. \\
\hline Deters & Imposes a penalty. \\
\hline Wears down & $\begin{array}{l}\text { Keeps coming back until the home wants closure to rid } \\
\text { themselves of the inspector. }\end{array}$ \\
\hline
\end{tabular}




\begin{tabular}{|c|c|}
\hline Strategy & Process \\
\hline $\begin{array}{l}\text { Changes resource } \\
\text { allocation }\end{array}$ & $\begin{array}{l}\text { Sanctions withheld only if there is a change in resource } \\
\text { allocation. }\end{array}$ \\
\hline $\begin{array}{l}\text { Voluntary acceptance of } \\
\text { responsibility on the spot }\end{array}$ & $\begin{array}{l}\text { By asking a question, causes a professional to jump in and } \\
\text { accept responsibility to put something right immediately. } \\
\text { This and the next five are motivational interviewing effects. }\end{array}$ \\
\hline $\begin{array}{l}\text { Voluntary acceptance } \\
\text { of responsibility in a } \\
\text { plan of correction }\end{array}$ & $\begin{array}{l}\text { Asking the right questions brings about a long-term plan that } \\
\text { accepts responsibility. }\end{array}$ \\
\hline Root-cause analysis & $\begin{array}{l}\text { Asking the right questions induces an insightful root-cause } \\
\text { analysis. }\end{array}$ \\
\hline $\begin{array}{l}\text { Trigger continuous } \\
\text { improvement }\end{array}$ & $\begin{array}{l}\text { Asking the right questions reveals the benefits of } \\
\text { commitment to continuous improvement. }\end{array}$ \\
\hline Trigger consultancy & $\begin{array}{l}\text { Asking the right questions persuades the home to hire in } \\
\text { help from a consultant. }\end{array}$ \\
\hline $\begin{array}{l}\text { Stimulate the home's } \\
\text { deliberative problem- } \\
\text { solving }\end{array}$ & $\begin{array}{l}\text { Asking the right questions is a catalyst of problem-solving } \\
\text { conversations at a staff meeting or other forum. }\end{array}$ \\
\hline Triple-loop learning & $\begin{array}{l}\text { Inspector spreads generative learning from mistakes in one } \\
\text { part of a facility to another and to one facility from another. }\end{array}$ \\
\hline Educates & Provides in-service training on the spot. \\
\hline Builds self-efficacy & Helps management and staff to see their own strengths. \\
\hline Awards and grants & Nominates the home or staff for an award or grant. \\
\hline Empowers & $\begin{array}{l}\text { Empowers friends of compliance within the organisation } \\
\text { through some combination of the above strategies that puts } \\
\text { pro-compliance factions of the organisation in the driver's } \\
\text { seat. }\end{array}$ \\
\hline Trigger pre-emption & $\begin{array}{l}\text { The home fixes problems before the inspector arrives to } \\
\text { pre-empt the deployment of any of the above strategies. }\end{array}$ \\
\hline $\begin{array}{l}\text { Trigger third-party } \\
\text { engagement with any/ } \\
\text { all the above }\end{array}$ & $\begin{array}{l}\text { A word to an advocacy organisation, a key shareholder, } \\
\text { a lending bank, the media, a provider association, a tort } \\
\text { lawyer, the ombudsman, the residents' council, relatives. }\end{array}$ \\
\hline
\end{tabular}

Schell-Busey et al.'s (2016) meta-analysis shows that regulatory inspection probably works in improving compliance with laws more than it should reasonably be expected to work based on a deterrence theory of corporate compliance. Indeed, their systematic review suggests that deterrence has no effect on its own; what works is a mix of regulatory enforcement strategies that inspectors deploy. Deterrence is often one of them. The same has been shown empirically to be true for peacekeeping; it does not always work, but it works best when it has a multidimensional regulatory and welfare mix (Doyle and Sambanis 2000, 2006; Walter et al. 2020). Thin reeds of enforcement directed against disparate forms 
of organisational power only work when they are bound together. This is not to deny that different regulatory strategies can be bound together in incompatible, counterproductive and mutually defeating, rather than mutually reinforcing, ways. Gunningham and Grabosky's (1998) Smart Regulation has given us a splendid beginning to understanding the particularities of where synergies in a regulatory mix are positive and where there is incompatibility among combined strategies. Notwithstanding the imperative for more fine-grained understanding, the possibility of productively binding together a mix of tools is good news for a theory of crime and freedom. It means that in corporate crime enforcement, peacekeeper enforcement against war crimes and reintegrative hotspot policing of street crimes, policymakers can do great things to reduce crime while rarely deterring through the clang of the jailhouse door, or even arrest.

This chapter argued that deterrence failure is a major impediment to effective control of organisational crime. It made a case for two strategies that can beat defiance, the deterrence trap and other corporate counterstrategies that make for deterrence failure:

1. Replace narrow, formal and strongly punitive responsibility (the 'find the crook' strategy) with broad, informal, weak sanctions (dialogic regulation) that touch many softer targets.

2. Separate enforcement targeting from identification of the actor who benefits from the wrongdoing.

Now a third strategy is added:

3. Rely heavily on street-level bureaucrats who mobilise what Peake and Forsyth (forthcoming) call the 'relational state'-a wide mix of preventive strategies, each of which is weak as a standalone strategy yet can be strong when woven into a fabric of relational prevention. These street-level relational regulators can be police, state, self-regulatory or NGO inspectors, state or NGO welfare supporters or citizens who mobilise collective efficacy at street level.

In fact, an astute, mutually supporting mix of these is needed. For confronting domination by the commanding heights of corporate power, while community groups are important third-party regulators (Braithwaite 2008), leadership from state regulators is imperative. Sometimes state regulators from developing countries who confront a global corporate 
colossus need backup from an international regulator like the International Labour Organization for labour rights abuses and from rights NGOs, the international trade union movement and more, in a web of networked governance that substitutes for weak state governance (Braithwaite and Drahos 2000; Braithwaite 2006b). For the most disadvantaged targets of law enforcement, who have suffered most discrimination by the state, a community-led mix tends to be superior to a state-led mix. Yet the state remains critical to any mix. State healthcare support is often critical to the mix. If a man pulls a knife and citizens of his community cannot persuade him to put it down, state police are also imperative.

At the macrolevel of the polity, the combination of these strategies means dialogic regulation combined with robust separations of powers within and between the public, private and community sectors. The number of third-party enforcement targets is greater to the extent that the organisational world and the political system have richer, more plural separations of powers. For example, under a plural separation of powers, the media baron who sells editorial support and biased reporting to a politician in return for the promise of a television licence or approval of a monopolistic media merger might, in a more effective republic, have their power checked by:

- courts of law

- a statutorily independent broadcasting authority that allocates licences only to fit and proper persons and has the capacity to investigate in cases of noncompliance

- industry association self-regulatory bodies

- a press council

- corporate charters of editorial independence

- a vigilant journalists' association that requires its members to comply with a journalists' code of ethics

- oversight committees of the legislature that investigate abuses of power by the executive, and other (separate) parliamentary committees that check diligent performance of the duties of independent regulators

- public interest groups that are granted standing to lodge complaints to all the foregoing institutions

- audit committees of boards of directors (all of whom are outside directors) with a remit to adjudicate complaints against management for ethical abuses 
- corporate ombudsmen with public reporting capabilities

- ethical investment funds with an investigative capacity they use to put activist shareholders on notice about abuses of power in media corporations.

Separations of powers both within and between the private and public sectors are important to controlling such abuses of power, as is countervailing power from institutions of civil society that muddy any simple public-private division. Moreover, the more potential targets of third-party enforcement such separations of powers throw up, the better is the chance that one of them will be a caring soft target with leverage over the abuser of power. They can be sufficiently caring for the simple device of a regulatory dialogue to move that third party to use their leverage to stop the abuse. Because they care, they might trigger internal reforms to prevent recurrence or trigger the private justice system of the organisation to discipline those responsible for the abuse.

Thus, the richer and more plural are the separations of powers in a polity, the less the society needs to rely on narrow, formal, strongly punitive regulation targeted at the beneficiaries of the abuse of power. The more we can rely on a regulatory dialogue that appeals to the sense of social responsibility of all actors who share an overdetermined capacity to prevent the wrongdoing, the more persuasion can replace punishment. The reasons for this are that the more hands into which powers are separated: a) the more likely it is that one of those actors with power to prevent will be an ethically caring target, and b) the more third parties there will be who do not benefit from the abuse themselves, but who hold power over the abuser. Put another way, the more plural are the separations of power: a) the more overdetermined is the capacity to prevent abuse; and b) the more cases there are of disjuncture between an interest in the abuse and capacity to prevent it. All this means that societies can grow more points of engagement with responsible actors who can mobilise collective efficacy for prevention inside organisations and institutions. In this way, preventive relational public or self-policing more regularly becomes a strategy that works. 
The final chapter of this book argues, furthermore, that these insights are critical to understanding how it is possible for weak social movement actors to defeat mighty states with large armies and wads of cash. Webs of reward and coercion are the master's tools that give masters an advantage over the dominated; webs of dialogue are where social movements enjoy comparative advantage over masters, partly because they can be mobilised to divide and conquer masters. Commitment to a politics of agonistic pluralism that is nonviolent is not only good for freedom; it is also good for political effectiveness in resisting hegemony.

\section{Plural private separations; plural public separations}

This chapter seeks to correct the bias of the republican tradition of political thought towards a focus on separations of public powers. Yet the arguments advanced are as relevant to the abuse of power by police as they are to the abuse of power by a private media organisation or internet platform. The head of state who rigs electoral boundaries is a hard target because nothing is more important to their career than the election outcome. Citizens who ask a judge to overturn the head of state's electoral rigging are approaching a softer target because the judge does not benefit from the election result in the way a head of state does. The traditional separation of powers between executive government and the judiciary can deliver the benefits revealed in our analysis of disjunctions between interest and preventive power.

Three separations of public power (executive, legislature, judiciary) are a narrowed plurality. Antifederalist separations of power (in some prerevolutionary US state constitutions), as with the US federal constitution, aspired to avoid the concentration of power (as did its private-sector analogue in antimonopoly law). In the most uncharitable reading of this arrangement, each branch is left alone to abuse power without too much interference within its own sphere from the other branches of government; a strict separation of powers simply assures that the sphere of each is not too broad. This would be uncharitable, however, because in all the early 
US state governments, while each branch had spheres of independence from the other branches, they also had spheres where their power was checked by the other branches of government (Flaherty 1996). ${ }^{7}$

Even so, the reconceptualisation of the rationale for the separation of powers in this chapter implies that in debates on the separation of public powers, attention is needed not just to assure the independence of honest judges from corrupt parliamentarians and corrupt executive governments (and vice versa). Attention is also needed to make corrupt, self-serving, nepotistic judges who flout the rule of law, patrimonial parliamentarians and corrupt executives vulnerable to the power of the other branches. One of the problems to confront if we are to make progress with some of our tougher problems, like police violence and corruption, is how to deal with pleas that any encroachment on the independence of the police via accountability to the elected government will take us back to a world in which the police lock up whomsoever the ruling political elite tells them is a troublemaker. How do we get universities that are fearless in undertaking research of which the state disapproves, yet that do not use this independence to become dominated by corporate interests that pay them fat research funding?

The answer proposed is to have a police force and a university that are sufficiently autonomous from state power, business power, church power, media power and the power of disciplines and professions to not be dominated by them. Part of their resilience in the face of any single source of domination will come from their very dependence on all those other sources of power. We need police that are vulnerable to publicly reported surveys of citizen satisfaction with the respect police show for rights (Braithwaite 1992), to meetings of police indigenous liaison committees,

7 Yet, late in his career, no less a republican figure than Thomas Jefferson-much influenced by John Taylor's (1950) book An Inquiry into the Principles and Policy of the Government of the United States — became an advocate of a total separation of the powers of the three branches, rejecting the dominant view of John Adams and the federalists that there should be some overlapping so there could be mutual checking of power. For Taylor, '[i]nstead of balancing power, we divide it, and make it responsible' (by which he and Jefferson meant all three branches must be responsible to the people by direct election) (Taylor 1950: 88; Vile 1963: 163-70). The late eighteenth-century French constitutions also rejected the idea of checks and balances in favour of a strict separation of powers, at least until the lessons of Maximilien Robespierre and Napoleon Bonaparte had been learnt. These were lessons about the fragility, adversarialism and vulnerability to tyrannical coups d'état of a purist democratic separation of powers (see Vile 1963: 198-99). Madison had foreseen that the best way to preserve the separation of powers was 'by so contriving the interior structure of government as that its several constituent parts may, by their mutual relations, be the means of keeping each other in their proper places' (Hamilton et al. 1963: 302-19). 
vulnerable to losing some of their budget to night watch committees of indigenous elders, to meetings of the police-LGBTIQ liaison committee, to meetings with local businesses concerned about break-ins, to meetings of local citizen groups, to criticisms made at restorative justice conferences that a police officer used excessive force, to the ombudsman, to parliamentary committees, to royal commissions to investigate matters of extraordinary malfeasance, to a free and fearless press, to the council for civil liberties, to the judiciary and to an executive government that will sack the commissioner if there is reasonable suspicion that he or she is corrupt or recruits violent police. After 200 years of ugly tyranny in nations with beautiful constitutions, it is no longer persuasive to suggest that a separation of state powers will ensure the government 'will be controlled by itself' (James Madison, in Hamilton et al. 1963: 323).

In other words, a police service that is enmeshed in many webs of interdependence will be vulnerable to the many when it corruptly does the bidding of one or the few. This might be the way of resolving the dilemma of independence for different branches of government versus the checking of power between them. The checking of power between branches of government is not enough. The republican should want a world in which the different branches of business, public and civil society power are all checking each other. While the broad principles here are clear, the nuts and bolts of checks and balances, of independence and interdependence, require contextual deliberation for any given source of power. Clearly, there must be some sorts of power against which a police service must be protected by law ('Arrest this man or we will cut your budget'). Republican theory of the sort Braithwaite and Pettit (1990) endorsed requires detailed empirical investigation of the different ways of organising independence and interdependence to discover a set of institutional arrangements most likely to maximise freedom as nondomination. At the very least, a clear principle of separating powers is that there are enough actors with independence and preventive capacity such that one of them can be moved by dialogue to stop the abuse.

In the public arena, the literature on the separation of powers bequeaths to us a variety of reasonably well-understood heads of public power that might be separated: different houses of parliament, levels of government in a federation, lower versus appellate courts, administrative appeals tribunals, an independent public service commission, and so on. While it is a tricky business to put together or tinker with a robust public architecture of powers, at least we have some sense of the elements with 
which we might work. In contrast, the separation of private powers is comparatively under-researched. Here, most readers will need some elementary sense of what might be involved in separating private powers. The next section is a preliminary foray into what might be at issue.

\section{How to separate powers in the private sector}

The law review literature on corporate governance provides useful guidance on accomplishing separations of powers in the private sector, but not useful enough. The concentration tends to be on the separate powers of shareholders, directors and managers (Eisenberg 1975; Kiiwan 1995). Important separation of power issues are at stake here, such as whether a majority of members of the board of a company should be unrelated directors, meaning they have no business dealings with, nor a management position in, the company; whether the nominating committee for the appointment of new directors should have no management directors on it; whether it should be forbidden for the CEO to be chair of the board; whether there should be a bicameral board with a supervisory board as in Germany, France, the Netherlands and Indonesia; and generally how to give outside directors a role that is more than that of the CEO's 'pet rocks'. There is certainly merit from a republican point of view in engendering shareholder democracy, encouraging activist shareholders to call management to account, securing representation for minority shareholders on the board and effective monitoring of the board by institutional shareholders. When the New York Stock Exchange first required a board audit committee of nonexecutive directors as a condition of listing on the exchange in 1977, this was a significant step for the separation of private powers. It spread to many parts of the world. Long before that, in the English Registered Companies Act of 1862, a more important step was requiring companies as a matter of law to be audited by a professionally certified auditor. This is the well-understood end of the separation of private powers. A useful literature already exists on how to make these separations work better: how to improve shareholder accountability, restructure directors' duties, bring board audit committees to life and improve the performance and independence of auditors. The emphasis on the separation of powers between management and the two other branches of corporate governance neglects the main game, however, which is separation within management. With private power, more so 
even than with public power, the power in the hands of the other branches of governance is extremely modest compared with the concentration of power in the executive, the top management team.

Therefore, internal auditing within the firm that enjoys independence from line management is important. It must report to board audit committees rather than just management, for example. This is not just financial auditing, but auditing of equal employment opportunities, labour law more broadly, environmental, safety and competition law compliance, tax compliance, and more. In multinational corporations, the independence of local auditors, especially for compliance with matters like the US Foreign Corrupt Practices Act, can be best secured by auditors from one national subsidiary auditing auditors from another national subsidiary. Christine Parker (2002) showed how compliance professionalism inside corporations can be a bridge that is as accountable to a particular kind of compliance professionalism (for example, environmental) outside the firm as it is to the firm. Sensibilities and compliance techniques from outside the firm filter into the firm through the compliance professionalism network. Valerie Braithwaite and Janine Bush's (1998) research showed that Australian firms that had the best affirmative action compliance for the benefit of women were those in which the affirmative action officer of the corporation had the best feminist networks, particularly with other affirmative action officers across many firms.

This corporate compliance literature is rich on how collective efficacy is built in professional communities that stretch between professional associations outside and across subsidiaries within corporations. This is bridging capital, bridging professional collective efficacy. This bridging is fundamental to understanding how corporate compliance with laws works when it does work. One of the most effective programs for getting international corporations that were paying no tax in Australia to selfregulate their profit-shifting to avoid tax (for example, to tax havens) did not so much involve direct collaboration between the Australian Taxation Office and the culpable firms. Rather, the collaboration was between the tax office and the major outside accounting firms that were doing the firms' tax work. There was a new line of business in this for the accounting firms, so they were the soft targets. The tax office co-designed with them a responsive regulatory pyramid of enforcement escalations that would occur unless there was voluntary commitment from their clients to higher-integrity tax compliance. The research concluded that the program delivered an extra billion dollars in tax revenue for each million spent on 
the co-designed collective efficacy of the compliance program (Braithwaite 2005b: 89-100). On this view of collective efficacy for corporate crime prevention, the collective efficacy of epistemic communities of internal and external gatekeepers to corporate power delivered. They delivered through dialogue and the co-design of compliance systems that guaranteed a degree of independence for the gatekeepers of the separation of corporate powers. More detail on how this has worked in companies can be found in Fisse and Braithwaite (1993) and Braithwaite (1997).

The globalisation of business has enabled new separations of powers and new answers to the question: 'Who guards the guardians?' At Exxon, IBM and Big Pharma, Brent Fisse and I found that compliance auditors from one country regularly travelled to subsidiaries in another country to audit the quality of their auditing. The Asian regional office auditors might audit the head office audit group in New York. Arranging guardianship in a circle is an advance on the historical practices of organisations like Exxon and IBM, which, akin to many police departments, rotted like fish from the head down. Every Mafia boss knows if you corrupt the police commissioner, the rest of the organisation is not likely to be a problem. Braithwaite (2006a) has developed more fully the republican ideal of arranging guardianship in a circle (illustrated in Figure 6.1). The only hierarchical solution to the corruption of nth-order guardians is to add an $\mathrm{n}+1$ th-order guardian. Then what happens if the $\mathrm{n}+1$ th-order guardian is corrupted? If, instead, we arrange guardians of accountability in a circle (see Figure 6.1, right side), each guardian can be a check on every other guardian. We can escape from the infinite regress of hierarchical accountability. The more separated public and private powers there are in a polity, the richer can be the circular checking of one guardian by many others.

In the world of corporate governance, progress is slow to bring into the circle utterly external watchdogs who do not depend on the corporation for an income. In Australia, consumer movement nominees on the Banking Ombudsman Council have access to the consumer complaint records of private banks and have a public reporting responsibility, but this has been overwhelmed by the volume and secrecy of consumer abuses. 
Guardian n+1

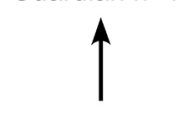

Guardian $n$

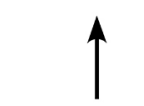

Guardian 2

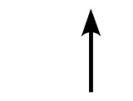

Guardian 1

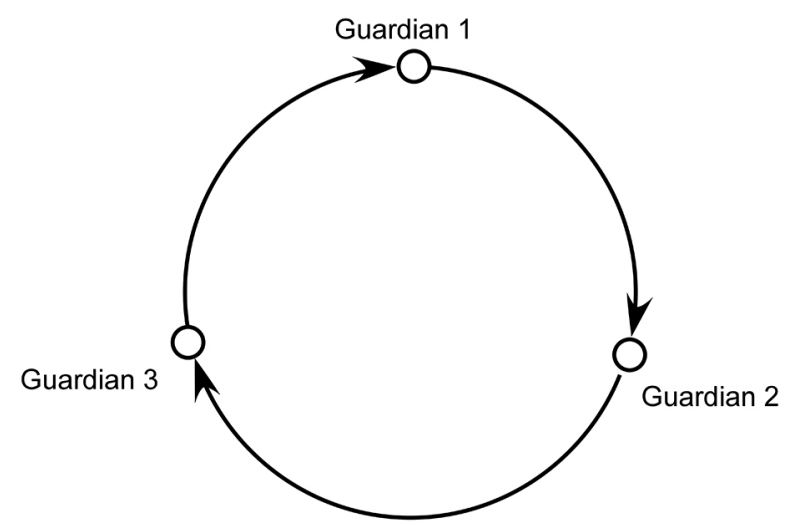

Figure 6.1 Models of hierarchical accountability and a circular republican conception of accountability

Accomplishments in widening the circle of guardianship to give outsiders a window into the audit performance of companies arose under the European Union's Eco-Management and Audit Scheme (EMAS) (EEC 1993). These were voluntary standards, yet they had significant force in a world in which many major purchasers and insurers required EMAS certification in environmentally high-risk industries. EMAS required companies to demonstrate continuous improvement in reducing environmental impact and product stewardship to an external environmental auditor. The report of that external auditor is generally publicly available and therefore can be examined by green groups on the lookout for environmental scandals. Unfortunately, some civil society auditing of environmental, fair trade, labour standards and animal rights compliance has tended to become captured, even dominated, by downstream retail interests (Sarfaty 2021). Some dominating retailers just want to sell more eggs via a low-cost path to labelling eggs 'free range' (Parker et al. 2017). Audit reports are sometimes less public than they should be. There is no need for despair about this; we must do more creative work to put in place more countervailing powers against retailer domination, against fraudulent retailer claims and for transparency. It requires pluralism that is more agonistic (Chapter 12).

There is a longer history of the empowerment of constituencies internal to the corporation, which have very different interests from management and affiliations to power bases outside the organisation. The leading example is elected union health and safety representatives who report both to management, which pays them, and the union, which legitimates 
them through democratic and deliberative accountability to workers, as discussed in the previous chapter. Rights of access to safety data have long been negotiated as a matter of contract between the union and the employer (Braithwaite 1985: 8), or as a matter of public law. These rights of access are sometimes checked by union-employed safety inspectors who conduct inspections of workplaces independently of state inspectors. In the case of large unions like the United Mine Workers of America during the 1980s, these could be many dozens in number (Braithwaite 1985). Empirical comparisons of high-accident and low-accident coalmines found that both safety directors and miners in mines with low accident rates reported that the union put greater pressure on management for safety through bargaining and dialogue (Braithwaite 1985). In Australian coalmines, elected worker inspectors do an independent check of a mine before a shift starts to double-check the assessment of company safety staff that levels of methane and other fundamental concerns are under control. Their assessment of the safety of the workplace is written in a record book at the entrance to the mine, which is available to all workers and to government safety inspectors. Union inspectors have a legal right to prevent or stop work at a mine on safety grounds until such time as a government safety inspector can come to the mine to adjudicate whether the safety stoppage is justified. This is quite an impressive separation of private powers that existed in the British Empire for more than a century and long existed in mine safety auditing in Japan, the United States, France, Romania and Poland (Braithwaite 1985: 9-10).

Professions are also important external-internal agents. A corporate circle of accountability is less closed to the extent that a general counsel who is a member feels an allegiance to the ethics of the legal profession that approaches in strength their allegiance to the corporation, or an accountant who feels ethical responsibility to accountancy's professional standards. Western nations are witnessing a proliferation of new professionalisms relevant to the penetration of corporate accountability by allegiances to values from outside the company. The 1990s in Australia saw a take-off of professionalism in environmental auditing, occupational health and safety and pharmacology (especially important in the pharmaceutical industry) and with the Society of Consumer Affairs Professionals in Business, the Institute of Compliance Professionals and the Regulatory Affairs Professionals Society (Parker 2002). In the United States, growth in corporate compliance staffing has been almost exponential during the past three decades (Haugh 2021). 
Tempering power cannot work without a level of transparency that renders abuses in one area visible to another sphere of power. A recurrent abuse in the pharmaceutical industry occurs when the production manager of a plant, who is paid performance bonuses and promoted based on getting product out of the plant, overrules a finding of their quality-control manager that a batch of drugs does not meet specifications. The chances of a batch of drugs that just fails to meet specifications causing side effects that would be sheeted home to this failure are slight, while the payment of the production manager's bonus may be a certainty, but only if they get the batch at issue out on time. Hence, the incentive for the manager to break the law.

A simple solution to this problem was adopted by some of the more quality-conscious pharmaceutical corporations in the 1970s and has now been mandated in the laws of many countries. This is that a production manager is not allowed to overrule a quality-control judgement on a batch of drugs. It can only be done over the signature of the CEO. The effect is to make transparent the perverse incentives the firm creates for the production manager to break the law. Another effect is to taint the CEO and people who advise them with knowledge (the reverse of a policy of a vice-president responsible for going to jail). The final effect of this law is to strengthen the hand of quality control managers against the normally more senior production managers. CEOs in practice are reluctant to overrule quality control recommendations because the cost of redoing one batch of drugs is a comparatively minor matter to them and is a good way of sending a message to production managers to improve their performance on quality. The prospect of a batch causing a fatality, however remote, could be fatal for the $\mathrm{CEO}$, as could the $\mathrm{CEO}$ tolerating a culture of sloppiness regarding quality. This, then, is an example of how a clever reporting architecture assures the separation of powers between quality control and production, prompts the need for dialogue on a quality culture that tolerates no errors on pharmaceutical specifications and shifts decision-making following the dialogue from a hard target with incentives to abuse power (the production manager) to soft targets with incentives to uphold the law (the CEO and the quality-control manager). These compliance dynamics of internally separated powers are possibly why the area of legal compliance that has improved the most, in a pharmaceutical industry in which corporate crime has generally worsened, is selfregulation of purity and sterility in drug manufacture (Dukes et al. 2014). 
In a more generalised way, the reporting policies Fisse and Braithwaite (1983) discovered at Exxon in the aftermath of its international bribery scandals were exemplary in the way they ensured that the soft targets in the company who could be moved by ethical dialogue got to know about the temptations to which hardened crooks within Exxon were succumbing. We have no data on how rigorously these policies were implemented throughout and for how long, though we have doubts. As with collective efficacy in high-crime neighbourhoods, it does not continue keeping communities safe from crime after collective efficacy shuts down. Collective efficacy for compliance with the law in firms like Exxon is always at risk of being shut down by new-broom top management ruthlessly focused on short-term profits and pumping the stock price. Corporate collective efficacy is about internally independent kicking of the corporate tyres to ensure compliance. Once that independence is crushed, corporate crime returns.

During those moments of reform at Exxon, the 'controller' explained to Fisse and Braithwaite (1983) that effective control meant having an organisation full of 'antennas'. All units of the organisation had a responsibility to report not only confirmed violations of the 'Business Ethics Policy', but also 'probable violations'. 'Probable violations' were defined by corporate policy as 'situations where the facts available indicate that a violation probably occurred, even though there was insufficient information for a definite determination'. Hence, one could not sit on a matter on the strength of it being 'under investigation'. However, an obligation to report 'probable violations' is a less potent protection than a responsibility to report 'suspected violations'.

When violations were reported, there was an obligation on the recipient of the report to send back a determination as to whether a violation had occurred and, if it had, what remedial or disciplinary action was taken. Thus, a junior auditor who reported an offence and heard back nothing about it knew their report had been blocked - sat on somewhere. They were then obliged to activate the safety valve channel direct to the board's audit committee.

If they did not, they were in breach of the Business Ethics Policy for failing to ensure the problem was either resolved or put before the board. Many companies have policies requiring the reporting of ethics violations, but not many have policies that oblige the reporter to ensure the report is not blocked. This is important because one thing we know about criminal 
corporations is that they are expert at structuring communication blockages into the organisation to protect top management from the taint of knowledge. This had been true when Exxon was paying off politicians around the world. Fisse and Braithwaite (1983) cited memos from this era with statements like '[d]etailed knowledge could be embarrassing to the Chief Executive at some occasion on the witness stand'.

\section{Summary of strategies for separating private powers}

The strategies of generic importance for separating private powers discussed so far are:

1. Better securing the separation of the powers of the three major branches of corporate governance: shareholders, directors and managers.

2. Better separating powers within management: quality and production, environment and production.

3. Expanding audit capabilities to a range of areas beyond finance: safety, antitrust, ethics, environment, labour standards.

4. Professionalising audit so that internal auditors have an external professional allegiance to balance corporate loyalty.

5. Abandoning hierarchies of accountability in favour of circles of accountability so that auditors audit auditors, ensuring that someone guards the guardians.

6. Allowing into the circle of accountability outsiders with interests that diverge from corporate interests: unions into safety management circles, consumer group representatives into consumer complaints handling, greens into environmental circles by mandated public reporting of corporate environmental objectives, and public reporting of audits of whether the objectives are attained.

7. Guaranteeing transparency, tainting soft targets with knowledge by institutionalising a safety valve reporting route direct to a board audit committee, to a corporate ombudsman or both.

8. In domains where serious abuse of power is a risk, independent reports on compliance to the board's audit committee from separate powers: line management, legal, audit, unions. 
9. Obligations on all employees to report suspected violations of law and violations of all corporate policies that involve an abuse of corporate power (for example, corporate ethics, environmental policies). Obligations to report the suspected violations directly to the board when the employee does not receive a written report that the matter has been satisfactorily resolved. Failure to meet this obligation must itself be an ethical breach that colleagues have an ethical obligation to report. In the context of corporate crime control, this is a key to collective efficacy that transcends the dominations of the extremely powerful.

For each of these strategies there is a debate to have about whether they should be mandated by the state, left to business or professional self-regulation or seen as demands that social movements must extract agonistically from private power.

\section{Many soft targets and how social change works}

As a general matter across the social sciences, the theory of persuading many soft targets may have its uses for understanding how social change works. My argument has been that the study of corporate and state crime has been afflicted with excessive pessimism grounded in the correct observation that it is difficult to deter an actor as powerful as the state, Amazon or Google. All states have their histories of criminalisation, periods when mafias, robber barons, drug lords or criminal stock market masterminds captured significant parts of the state. Equally, many states have put their criminalised past behind them, moving from a state with extractive institutions to states with inclusive and accountable institutions (Acemoglu and Robinson 2012), from predatory states to developmental states that institutionalise embedded autonomy (Evans 1995).

Realist international relations theorists are scathing about the irrelevance of international law. They ask why a state would ever comply with international law when it is against their interests; because there is no sovereign above states-the United Nations is not their sovereign; state sovereignty rules over the United Nations-states cannot be deterred by international law. International lawyers have found this realist challenge a dangerous one for their discipline. For the most part, their response 
has had little impact because they refuse in their rejoinders to reframe their referent. The problem of international lawyers is that they are just as wedded to the referent that international society is a society of sovereign states as are the realist international relations theorists. This is not to say that the rejoinders of international lawyers are without merit when they say that states are more than just rational actors pursuing their interests (for example, see the wonderful rejoinder of Chayes and Chayes 1998).

The more useful rejoinders, however, draw on work such as that of Ronald Mitchell (on the international law of oil spills at sea). Oil tanker owners often sailed under flags of convenience that made them undeterrable by the direct rule of any sovereign state. We saw how 98 per cent compliance with international law was achieved by broadening the range of regulatory targets to shipbuilders, classification societies, insurers and reinsurers, and more.

Putnam and Henning (1989) contributed an important reframing of the referent of international relations when they tackled the puzzle of how the G7-the seven most powerful sovereign nations on the planetat its Bonn summit of 1978 could settle a trade and economic policy agreement that every one of those sovereigns strongly opposed. It was not even a compromise in which one country won on this and another won on that. It was, from the perspective of all seven sovereigns, a loselose agreement they had signed. Putnam (1988) resolved the puzzle by showing that each of the trade diplomats of the G7 was actually sitting at two tables. Putnam's contribution was called the two-table theory of international politics. Ministers were sitting at the G7 table with the trade ministers of six other sovereign states with whom they were implacably in disagreement. But as they did their deals, they were also turning around to their table of domestic politics, which included representatives of other state bureaucracies, domestic business and domestic civil society. For example, one Bonn summit agenda item was reducing global fiscal imbalances by all major states increasing taxes on oil. None of the trade ministries of the G7 wanted that, but the environment ministries represented at the second table of domestic politics did for each of the seven states-as did some business interests that were invested in other sources of energy (nuclear power interests, coal interests, paradoxically, and renewables investors in hydro, for example) and environmental NGOs. While the trade interests at the first table were opposing each proposal put up by the other six trade ministers, the pro-oil-tax interests around the seven second tables were joining hands to build strong domestic pressure for consensus in 
favour of higher oil taxes as part of the solution in each of their seven societies. The oil tax hike did become part of the agreement. In other words, a collaborative problem-solving politics among many weak players defeated a confrontational politics mobilised by the interests of all the strong players who were used to getting their way at the first table.

Braithwaite and Drahos (2000) describe in similar theoretical terms how a much more important environmental agreement was reached that criminalised conduct that was killing hundreds of thousands of people by widening the ozone hole. This was the Montreal Protocol of 1987, which was accomplished in a different way by dividing the opposition of the strong and persuading US President Ronald Reagan to defect from the strong to join the more unified environmental coalitions of the weak (discussed in more detail in Chapter 12). The most important and effective international agreement for crime control in human history, according to Braithwaite and Drahos (2000), was the agreement to ban the slave trade. It mobilised the same strategy of dividing the strategic trade interests of the most powerful sovereigns in the world, as just one strong sovereign, then two, joined more unified social movement coalitions of the weak against slavery led by Christian churches. This was the first great victory of global social movement politics that showed the way for others to follow, such as the women's movement in globalising the right for women to vote in the early twentieth century and the international trade union movement beginning the globalisation of labour laws from 1919 (Braithwaite and Drahos 2000).

The theoretical interpretation here is to see this paradoxical outcome of the weak using the jujitsu of the strong against them in international politics as reflecting the results of Schell-Busey et al.'s (2016) meta-analysis of what works in corporate crime control. In fact, it is this result writ large. Pure deterrence does not work as well as a regulatory mix of many thin reeds. Just as Christian churches could transform a world that was mostly not Christian in the antislavery movement against the most powerful corporations and states in the global system, so churches are a better hope than criminal law-enforcement decapitation strategies for regulating Latin American drug cartels. The more promising approach involves churches peeling off some of the most powerful cartel leaders to a deal in which they disinvest their capital from drugs and human trafficking and invest it instead in the legitimate capital market. They can live a comfortable life this way without passing on to their children a future fearing a hail of bullets. The caring and ethical soft targets here are organised crime 
bosses who want a more decent life for their children than the life they have led. The template for how to do this is not in the criminological literature on organised crime but in the peacemaking literature on how religious leaders working with women's groups have persuaded the wives of insurgency leaders to then persuade their husbands to lay down their guns (Braithwaite et al. 2010b). Critics rightly say there is not a lot of justice as proportionality in these deals. Murderous insurgency leaders tend to get rich out of the power-sharing deal that forges the peace while the victims of their murderous conduct get only crumbs from the table of the peace deal. In the long run of history, however, what both groups get is justice as a better future for all their children-a more peaceful future. Consider Froestad and Shearing (2012) on post-Apartheid South Africa taking on justice as a better future. None of this is to say that the transition from Apartheid, from slavery, war, domination by drug cartels or environmental domination by the G7 is easy. It is hard, agonistic work, but we can make more progress by mobilising the collective efficacy of many weak players than by deluding ourselves with simplistic strategies of decapitating or deterring domination.

In sum, we can think of the mistake the international relations scholars made as failing to reframe the referent, to use the language of Chapter 2. The referent needed to move from the state to bits of the state and bits of international society. This is a dialogue of many weak bits coordinating to accomplish a jujitsu that flips the strong. It does the jujitsu by turning some of its own strengths against itself. This way of thinking about social change is a way of reframing thinking about why collective efficacy and restorative justice should be seen as theoretically promising ideas that have encouraging evidence of effectiveness. Chapter 9 contrasts them with the theoretical framing of 'swift and certain deterrence' directed at individual offenders as the theoretical grounding for Operation HOPE. It is not that the intervention techniques of Operation HOPE lack promise. Its problem, according to the diagnosis of Chapter 9, is that it is hobbled by a myopic theoretical focus on deterring individual offenders. Operation HOPE can reframe its referent to a community of care, as restorative justice has done and collective efficacy does (Chapter 11), if it is to grasp the theoretical possibilities in its intervention strategy. The genius of collective efficacy exists at many levels, and this is just one of them. But in shifting from unpromising and costly deterrence interventions to 
collective efficacy interventions, we shift from a focus on hard targets who are committed to criminal subcultures to the larger numbers of caring, responsible citizens who surround them.

As collective efficacy is built, a majority of the most caring soft targets tend to be women; conversely, when we target dominating criminals who are hard targets, we mostly target men. This plays into Messner and Rosenberg's institutional anomie virtue of feminising the frames of aspirational reference for freedom and crime control. Poor communities do well when they learn to value more than grabbing the material possessions of others, when they learn to value collective communitybuilding in which women are leaders in charting the better course. Likewise, in restorative justice circles, empirically, women do more of the speaking than men. Targeting a community of care in our interventions mobilises many soft targets and energises them through the 'collective effervescence' of the restorative circle (Rossner 2013).

\section{Conclusions so far}

A standard rationale for the separation of powers is deterring the abuse of power with countervailing power. Deterring the abuse of power, be it private or public, is not something societies are good at. Problems like police corruption, dumping of hazardous waste and corporate fraud bounce back after each wave of scandal and reform (Sherman 1978). An increasingly coherent theoretical and empirical literature can now make sense of why deterring the abuse of power so often backfires. Emotive defiance, cognitions of stigma and procedural injustice, psychological reactance, the deterrence trap, the retribution trap, the compliance trap and rational countermeasures are among the reasons big sticks often rebound (Braithwaite 1997; see also Chapter 9). This book shows that all of these mechanisms apply to powerful actors; several of them have more force with powerful than with powerless actors. Chapter 9 will show that defiance is greatest with the powers which the powerful care about most. Braithwaite (1997) shows that potent corporate counter-deterrence strategies are also most likely with the power corporations most care about dominating. This generally means defiance will be most potent with the commanding heights of organised power. 
The first solutions to these problems considered are to:

1. replace narrow, formal and strongly punitive responsibility with broad, informal, weak sanctions that touch many soft targets

2. separate enforcement targeting from identification of the actor who benefits from the abuse.

Together, (1) and (2) imply: a) strong separations of power within and between both the public and private sectors, combined with b) another republican regulative ideal-problem-solving dialogue. The richer and more plural are the separations of powers, the more overdetermined will be the capacity to detect and prevent abuse of power. The more actors there are with this preventive capability, the more likely it is some of them will be soft targets who can be persuaded to check the abuse of power by simple and cheap discursive appeals to their virtue, or at least to interests different to those of the actors who are abusing power. The more that institutions for the control of abuse of power are based on moral reasoning rather than deterrence, the more public-regarding actors with preventive capability there will be to stand up against domination.

Deterrence is certainly needed when dialogue fails to control the abuse of power. Incapacitation is more strongly needed when deterrence fails (Chapters 9 and 10). But the more we can succeed in keeping deterrence and incapacitation in the background, the better are the prospects that separations of powers will check the abuse of power through moral suasion, and the better will be the chance that it will do so in a way that enhances rather than hampers economically efficient markets in virtue.

An interesting implication of this for republican political theory is that separations of powers and dialogic appeals to the virtue of citizens are not just separate republican ideals. Separations of powers create a world in which dialogue can displace sanctioning as the dominant means of regulating the abuse of power. These republican prescriptions are not only coherent in the sense that separations of powers and dialogic reconstitution of interests help secure freedom as nondomination. Deliberative democracy is causally dependent on separations of powers.

We have shown that if appeals to the virtue of soft strategic targets are to work, the form separations of powers must take is much more plural than the traditional separation of the legislature, executive and judiciary. The more richly plural are the separations of public and private powers, 
the more likely it is that the dependence of each guardian on many other guardians will secure their independence from domination by any one of them.

This theory of republicanism amounts to a rejection of the radical Jeffersonianism of the strict separation of powers that became influential in the early nineteenth century, and that was represented in the French Constitution of 1795. Simply dividing power and making it directly accountable to the electorate, preventing judges from meddling in the affairs of the legislature and vice versa, were part of a romantic theory even then-one that was bound to give birth to adversarial struggles for control that would deliver the likes of Napoleon Bonaparte. The romantic theory of this century has been that antitrust law could democratise the new private power simply by dividing it. ${ }^{8}$ A pragmatic republicanism for the burgeoning private power of the twenty-first century will give more emphasis to the checking-of-power part of the republican ideal; it will pluralise the separation of powers, while rejecting any aspiration that each divided power be fully independent. Rather than having a few autonomous branches of governance, many semi-autonomous powers will recursively check one another. This means rejecting the status quo of the separation of powers, rejecting radical Jeffersonianism and creatively radicalising Madison for a world of new and disturbing concentrations of private power.

A good concluding illustration of how important these ideas are for crime reduction and freedom enhancement is reform in the United States in the early 1990s that steeply reduced the number of nursing home residents who were physically restrained: it declined from 42 per cent of all nursing home residents in the United States being physically restrained in the late 1980 s to 4 per cent by early this century, with most of the decline occurring with the reforms in the first two years of the 1990s (Braithwaite et al. 2007: 44). Collective efficacy in the community of gerontological professionals to liberate the elderly was led by several innovative administrators who

8 Maximising the breaking up of private power through antitrust law might create inefficiently small firms. This is politically unsustainable in a world of intense international competition. Even if one could do it, why would one want to? In some senses, it is easier for state and civil society to demand the kinds of separations of power and dialogic justice discussed in this chapter from one profitable large firm than from a dozen small struggling firms. A conception of the separation of powers as simply dividing or breaking up concentrations is rarely attractive or realistic in the contemporary world. That is by no means to deny that there will be occasional contexts in which the best strategy to control domination is to break up a monopoly. This is also a strategy that the rule of competition law rightly provides. 
built profitable 'restraint-free' nursing homes as a proof of concept. It was driven most importantly by an inspiring and agonistic social movement to 'Untie the Elderly' and by the retraining of street-level regulators to ask hard questions about why residents were being restrained. Inspectors recorded noncompliance when poor answers were given. There was also regulatory pressure during the 1990s to ensure that physical restraint was not replaced with chemical restraint. This vigilance meant that chemical restraint also halved in the early 1990s. In the twenty-first century, however, a new epidemic of chemical restraint crept back into the system and cascaded to take it over. Lobbying leadership of Big Pharma by Purdue Pharmaceuticals, who had a strategy to increase opiate addiction of the aged, was critical in this regress. The lesson here is that, on a regular historical cycle, regulatory parameters must be reset to counter whatever forms of gaming have entered the system since the last cycle of reform. Whether it is hotspot policing or nursing home inspection, street-level preventive strategies work, but they do not keep working if the guardians of freedom stop kicking the tyres at street level.

These new separations of powers that untied the elderly were economically efficient because it turned out that the corporations that sold restraints were peddling a false message that unless residents were carefully restrained, nursing homes would be sued for failing to prevent falls. The evidence showed that more nursing homes were sued by families after loved ones slid down in their chair and were strangled on their restraint than were successfully sued for falls of unrestrained residents (Braithwaite et al. 2007). Mercifully, Purdue Pharmaceuticals was ultimately bankrupted by suits and criminal enforcement over its creation of the opioid epidemic. These new separations of powers in aged care delivered one of the most unrecognised but fundamental advances of freedom in America in the twentieth century. Aged care accomplished this while reducing private litigation, while improving compliance with the law that reduced fines and while increasing efficiency and profitability. There is no doubt, however, that excess in separations of powers in other circumstances does reduce rather than increase efficiency. This is true for separations of powers in both the public sector and the private sector. This challenge is confronted in the next chapter.

Hence, in subsequent chapters, we must think more deeply about the character of what is required for a society that has low crime, low domination and that flourishes with freedom. The next chapter traverses the micro-macro in a more comprehensive way, putting emphasis on 
the importance of strong individuals for high freedom and low crime. But strong individuals do not appear from thin air. They come from strong families, strong schools, strong universities and collective efficacy in strong communities where it 'takes a whole village to raise a child'. More abstractly, these strengths require strong markets to be complemented and tempered by strong states, strong civil society and strong individuals.

\section{Looking forward to a macro vision of collective efficacy for freedom}

The next chapter argues that financial capital must be tempered by human capital, social capital, recovery capital and restorative capital. Collective efficacy is the most critical facet of social capital for crime prevention. Collective efficacy also does not appear from thin air. To deliver it at the level of all local communities, societies must get serious about scaling up recovery capital, restorative capital and prevention. The next chapter and Chapter 11 grapple with how the undominated, low-crime society moors a complex web of separated private and public powers to accomplish the scaling up of social capital. Chapter 7 considers Sun Yat-sen's thinking and leadership of a century ago when he was contemplating his Chinese republic. Authoritarian resistance to communism washed his republican vision into the bloodied soil of his beloved China. The key innovation of Sun Yat-sen's republican constitutions was a fourth branch of governance that drew on the wisdom from millennia of Chinese institutional history on how to complement an independent executive, legislature and judiciary. This fourth branch is an integrity and accountability branch of governance. I think of this fourth elected branch of non-party one-termers as the conductor of the richly separated powers of a society's orchestra. Its philosophy is to temper wisely the many separated powers arrayed in front of it. This is a complex and interesting art of government. Freedom's orchestra does not soar simply by getting each musician to play in tune.

Finally, Chapter 11 argues that the most extractive of states and economies are vulnerable to cascading civil wars and violent state crime. Wars do make strong states-a theme from Tilly discussed in Chapter 3. In contemporary conditions, strong states emerge in the aftermath of wars that escalate to the point of destroying old regimes. UN peacekeeping and peacebuilding can become for a period of transition perhaps the most important elements of the separation of powers. We have seen in 
this chapter that the effectiveness of UN peacekeeping in preventing war and crime is one of the strongest empirical relationships established by the discipline of international relations (Walter et al. 2020). This UN work is a profound source of hope for all societies. This is because, for example, if we want to look for the society that has the most inspiring institutionalisation of women's rights in its constitution, look to Nepal, where a vibrant women's movement institutionalised those constitutional rights in a 2006 peace agreement. That peace process put its polity in a more 'original position' with UN support-an original position where no political faction knew who would win the post-conflict election and all needed to sustain support from the women's movement by supporting the de-institutionalised domination of women (Braithwaite 2015).

One implication of understanding tempered and plural powers is that the next great innovations in the institutionalisation of freedom are most unlikely to come from stable, smug western democracies for reasons similar to why the next great genres of music that lift our souls may not be inspired by white westerners. What the West can do is become more cosmopolitan in the way it looks out to learn from the next Sun Yat-sen, the next Gandhi, the next Nelson Mandela, or the next Nepalese feminists. 
This text is taken from Macrocriminology and Freedom, by John Braithwaite, published 2022, The Australian National University, Canberra, Australia.

doi.org/10.22459/MF.2021.06 